Foss. Rec., 21, 137-157, 2018

https://doi.org/10.5194/fr-21-137-2018

(C) Author(s) 2018. This work is distributed under

the Creative Commons Attribution 4.0 License.

\title{
Growth patterns, sexual dimorphism, and maturation modeled in Pachypleurosauria from Middle Triassic of central Europe (Diapsida: Sauropterygia)
}

\author{
Nicole Klein $^{1}$ and Eva Maria Griebeler ${ }^{2}$ \\ ${ }^{1}$ Steinmann Institute, Paleontology, University of Bonn, Bonn, 53115, Germany \\ ${ }^{2}$ Institute of Organismic and Molecular Ecology, Evolutionary Ecology, Johannes Gutenberg University, \\ Mainz, 55099, Germany
}

Correspondence: Nicole Klein (nklein@posteo.de)

Received: 10 November 2017 - Revised: 29 January 2018 - Accepted: 2 March 2018 - Published: 25 April 2018

\begin{abstract}
Bone tissue, microanatomy, and growth are studied in humeri of the pachypleurosaurs Dactylosaurus from the early Anisian of Poland and of aff. Neusticosaurus pusillus from the Lettenkeuper (early Ladinian) of southern Germany. Histology and modeled growth curves are compared to already published data of other pachypleurosaurs. Therefore, we herein established growth curves for Anarosaurus from the middle Anisian of Winterswijk (the Netherlands) and for pachypleurosaurs from the Anisian/Ladinian of the Alpine Triassic (i.e., Neusticosaurus spp. and Serpianosaurus). Humeri of Dactylosaurus, Anarosaurus, and aff. $N$. pusillus, all from the Germanic Basin, usually display an inner ring of (pre-)hatchling bone tissue. In some samples this tissue is surrounded by a layer of perpendicularly oriented fine fibers, which could indicate the start of active locomotion for foraging or might be related to viviparity. However, pachypleurosaurs from the Alpine Triassic do not show this tissue. This in turn could be related to overall differences in the environments inhabited (Germanic Basin vs. Alpine Triassic). Histological comparison revealed distinct taxonspecific differences in microanatomy and bone tissue type between Anarosaurus on the one hand and Dactylosaurus and the Neusticosaurus-Serpianosaurus clade on the other hand. Microanatomical differences imply a different degree in secondary adaptation to an aquatic environment.

Life-history traits derived histologically and obtained from modeling growth were in general rather similar for all studied pachypleurosaurs. Onset of sexual maturation was within the first third of life. Asymptotic ages (maximum life span) considerably exceeded documented and modeled ages at death in all pachypleurosaur taxa. All traits modeled (more or less)
\end{abstract}

matched values seen in similar-sized extant reptiles. Growth curves revealed differences in growth and maturation strategies within taxa that could indicate sexual dimorphism expressed in different adult sizes and a different onset of sexual maturation. Differences in gender size and morphology is well documented for the Chinese pachypleurosaur Keichousaurus and for Neusticosaurus spp. from the Alpine Triassic. Birth-to-adult size ratios of herein studied pachypleurosaurs were consistent with those seen in other viviparous Sauropterygia, other viviparous extinct taxa as well as extant viviparous reptiles. Anarosaurus had the highest maximum growth rates of all pachypleurosaurs studied, which best conformed to those seen in today's similar-sized reptiles and is expected from its bone tissue type. The other pachypleurosaur taxa had lower rates than the average seen in similar-sized extant reptiles.

We hypothesize from our data that the considerably higher asymptotic ages compared to ages at death, early onset of maturation compared to asymptotic age, and viviparity reflect that pachypleurosaurs lived in predator-dominated environments.

\section{Introduction}

Sauropterygia is a diverse group of diapsid marine reptiles that existed from the late Early Triassic until the end of the Cretaceous (Rieppel, 2000). Their Triassic radiation was restricted to the near-shore habitats of the Tethys Ocean and connected epicontinental seas. It primarily involved shallow marine forms such as Placodontia, Pachypleurosauria, 
Nothosauroidea, and Pistosauroidea. The latter three form the Eosauropterygia (Rieppel, 2000). However, recently several new taxa of Eosauropterygia exhibiting a mosaic of pachypleurosaurian and nothosaurian characters have been described from the Middle Triassic of China (e.g., Jiang et al., 2008; Shang et al., 2011; Wu et al., 2011) that contest the monophyly of Eosauropterygia.

Triassic Sauropterygia is an interesting group for histological studies since they occur in high individual numbers in the bone beds of the Germanic Basin. The downside is that taxonomical assignment of isolated bones beyond group level is often difficult (e.g., see Rieppel, 2000; Klein et al., 2015a, b, 2016). Triassic Sauropterygia have been in the focus of several histological and/or microanatomical studies (Klein, 2010; Krahl et al., 2013; Klein et al., 2015a, 2016). The growth record was analyzed histologically and by growth curve modeling for Placodontia (Klein et al., 2015b) and Simosaurus (Klein and Griebeler, 2016).

Overall differences in bone tissue types and resulting growth curves indicate differing growth patterns and lifehistory strategies among Placodontia (Klein et al., 2015b) and Nothosaurus spp. (Klein et al., 2016; Klein and Griebeler, 2016). Unexpectedly, some placodonts from the Germanic Basin have the highest growth rates among Triassic Sauropterygia as suggested by fibro-lamellar bone tissue type and vascular pattern. Simosaurus and Nothosaurus spp. grew with lamellar-zonal bone tissue but have clearly increased growth rates when compared to modern reptiles, including crocodiles and varanids (Klein et al., 2016; Klein and Griebeler, 2016).

Pachypleurosauria appear during the early Anisian in the Germanic Basin and were thought to live in coastal, shallow marine environments (Gürich, 1884; Rieppel, 2000; Klein, 2012). They flourish during the Anisian/Ladinian of the Alpine Triassic of Monte San Giorgio (Italy, Switzerland; e.g., Sander, 1989; Rieppel, 1989, 2000) and also during the earliest Carnian in China (Liu et al., 2011). Dactylosaurus from Poland is the oldest taxon known (early Anisian) within localities from the Germanic Basin. Anarosaurus was described from the middle Anisian of Winterswijk (the Netherlands) and from the late Anisian of Remkersleben (Germany). Serpianosaurus and Neusticosaurus spp. are known from the Anisian/Ladinian of the Alpine Triassic of Monte San Giorgio. Neusticosaurus pusillus was also described from the Lettenkeuper of the Germanic Basin (late Ladinian) (Seeley, 1882), which is the only evidence for this clade outside the Alpine Triassic (Rieppel, 2000).

High individual numbers of the Chinese pachypleurosaur Keichousaurus and of the pachypleurosaurs from the Alpine Triassic allowed detailed studies of ontogenetic and intraspecific variation, clearly documenting sexual dimorphism in size and morphology (Sander, 1988, 1989; Rieppel, 1989; Rieppel and Lin, 1995; Lin and Rieppel, 1998; Cheng et al., 2009; Xue et al., 2015). These studies further revealed live- bearing (viviparity) in Keichousaurus (Cheng et al., 2004) and most likely also in Neusticosaurus (Sander, 1989).

Bone histological studies of midshaft regions in long bones (humeri and femora) of pachypleurosaur taxa (Sander, 1990; Klein, 2010, 2012; Hugi et al., 2011) revealed important information on their life history: Serpianosaurus reached sexual maturity in its 2 nd or 3rd year of life, and the oldest individual died in its 14th year (Hugi et al., 2011). Neusticosaurus pusillus and $N$. peyeri reached sexual maturity at an age between 3 and 4 and died between 7 and 10 years (Sander, 1990). The onset of sexual maturity started in $N$. edwardsii between the 4th and 7th year, and it reached ages older than 15 years (Hugi et al., 2011). Anarosaurus shows a much faster growth rate due to growing with a different bone tissue and vascular pattern when compared to Neusticosaurus and Serpianosaurus (Klein, 2010). It also displays stratification of its cortex by growth marks but skeletochronology has not been analyzed in detail yet.

\subsection{Mathematical growth models}

Fitting different growth models to a series of ages and respective bone lengths (as a proxy for body masses) derived from the annual growth record and preserved in a single bone is an objective method for finding the statistically best growth curve for an individual. From growth curves important life-history traits can be derived such as life span, age at which sexual maturity is reached, size at birth, asymptotic size (even if the individual under study died before reaching it), and maximum growth rate (if a mass estimate is possible for the individual). Estimates of traits derived help to understand how the environment and the shared evolutionary history shaped life-histories and trade-offs between traits in fossil taxa.

However, life-history traits themselves are not the only influence on the biology of fossils. Growth curve modeling also allows an objective estimation of birth-to-adult size ratios. This is not only possible for specimens with a complete and well-preserved growth record, but also for specimens with an incomplete growth record. The growth record in the innermost cortex can be incomplete due to resorption, remodeling, or fast growth of juvenile individuals. It can also be incomplete in the outer cortex because the individual died before it was fully grown. High birth-to-adult size ratios have been observed in viviparous extinct taxa including Sauropterygia and also in extant squamates (for a review see O'Keefe and Chiappe, 2011). High ratios are considered as being indicative of viviparity in extinct taxa (Renesto et al., 2003; O'Keefe and Chiappe, 2011).

While in extant animals, growth curves have been successfully applied to uncover sexual dimorphism (Stamps, 1993) this approach has so far - to the best of our knowledge not been applied to any fossil taxon. In extant lizards, males are often larger than females and grow for a longer period than females, but the opposite pattern also exists in this group 
(Cox et al., 2003). In many taxa (e.g., Anolis lizards) members of the larger sex also mature at older ages than members of the smaller sex (Stamps et al., 1994; Stamps and Krishnan, 1997). Such differences in asymptotic size and size at maturation are reflected in different shapes of growth curves and in their defining parameter values. For example, growth curves corroborated that female and male hatchlings of Anolis sagrei living in the same habitat start from an equal snout-vent length, but males reach higher asymptotic sizes and mature later than females (Stamps, 1993). Growth curves further document that in some taxa male and female lizards have comparable hatchling sizes, ages at sexual maturation, and a similarly shaped growth curve, but males reach larger asymptotic sizes under similar environmental conditions (e.g., Schoener and Schoener, 1978; Dunham, 1978, 1981).

Sexual selection can drive the evolution of sexual size dimorphism through intra-sexual competition or inter-sexual mate choice favoring larger or smaller size in one sex (Andersson, 1994). Niche portioning has also been suggested to drive size differences in sexes (Shine, 1989; Cox et al., 2007). Sex differences in age-specific mortality can lead to bimodal distributions of age at maturation within a population (Monnet and Cherry, 2002; Kupfer, 2007).

\subsection{Aim}

It is the aim of the current study to describe microanatomy, histology, and growth of the pachypleurosaur Dactylosaurus from Poland and of aff. Neusticosaurus pusillus from southern Germany. Results are compared to published lifehistory data from other Pachypleurosauria (Anarosaurus, Serpianosaurus, and Neusticosaurus) in order to investigate whether differences in life-history traits exist between taxa. Further on, based on histological data, growth curves are established and life-history traits derived from curves are compared to the specimen's growth record, to data from other Sauropterygia (Simosaurus, Placodontia), and to modern reptiles. It is additionally tested whether growth curves corroborate viviparity (in terms of large birth-to-adult size ratios) and whether they provide evidence for sexual dimorphism in asymptotic size and/or maturation in Pachypleurosauria.

\subsection{Institutional abbreviations}

MB.R. Museum of Natural History, Leibniz Institute for Research on Evolution and Biodiversity at the Humboldt University Berlin, Germany

PIMUZ Palaeontological Institute and Museum of the University of Zurich, Switzerland

SMNS Stuttgart State Museum of Natural History, Germany
Wijk NMNHL RGM (Wijk), National Museum of Natural History Naturalis, Leiden, the Netherlands

\section{Material and methods}

\subsection{Material}

Our pachypleurosaur sample represents material from the Middle Triassic of the Germanic Basin (Anisian and Ladinian; Lower Muschelkalk and Lower Keuper) and from the Alpine Triassic (Anisian/Ladinian). Early and middle Anisian (i.e., Lower Muschelkalk) samples are from the Gogolin Formation of Poland and the Vossenveld formation of Winterswijk (the Netherlands). Humeri from Poland represent a growth series ranging from 2.08 to $4.4 \mathrm{~cm}$ in length. Based on their morphology these humeri most likely represent Dactylosaurus (Nopcsa, 1928; Sues and Caroll, 1985; Rieppel and Lin, 1995; Rieppel, 2000). The humeri from Winterswijk all belong to Anarosaurus heterodontus (Rieppel and Lin, 1995; Rieppel, 2000; Klein, 2009, 2012) and have been partly studied before (Klein, 2010, 2012).

Humeri from the Lower Lettenkeuper (aff. N. pusillus) come from several localities of Baden Württemberg (southern Germany) and resemble the morphology of Neusticosaurus pusillus described from the Lettenkohle of Hoheneck, near Eglosheim (Fraas, 1881, 1896; Seeley, 1882; Sander, 1989; Rieppel, 2000). Neusticosaurus pusillus is the only member of the Neusticosaurus-Serpianosaurus radiation that was found outside the Alpine Triassic realm so far. Additionally, Neusticosaurus (N. pusillus and N. edwardsii) and Serpianosaurus from the Alpine Triassic were included in our study as well. Samples are taken from the studies of Sander (1990) and of Hugi et al. (2011). Histological and life-history data were compiled from these publications but thin sections of these taxa were also studied first hand. All humeri included in this study are listed in Table 1, which summarizes the histological and microanatomical features as well as the growth record preserved for all specimens studied by us.

\subsection{Methods}

The humeri were photographed and their proximodistal length was measured (Table 1). Where possible, humeri were sectioned exactly at the narrowest point of the midshaft where the growth center is located. However, it was not always possible to cut the humerus exactly at midshaft due to preservation (Table 1). Thin sections were produced following standard petrographic methods (e.g., Klein and Sander, 2007) and were then studied and photographed with a Leica ${ }^{\circledR}$ DM 750P compound polarizing microscope equipped with a digital camera (Leica ${ }^{\circledR}$ ICC50HD). Crosssections of larger humeri are the result of compiled microscope photographs. The bone histological terminology fol- 
Table 1. Material, measurements, locality, stratigraphic information, microanatomy, histology, and growth record. Taxa appear in stratigraphic order, humeri are listed from small to large. Abbreviations: bc, bone compactness; cav., cavity; cc, calcified cartilage; eb, endosteal bone; ec, erosion cavities; er, erosion; gm, growth marks; htb, hatchling bone tissue; med. reg., medullary region; sl, sharp line; sm, sexual maturity; $\times$, was not calculated.

\begin{tabular}{|c|c|c|c|c|c|c|}
\hline $\begin{array}{l}\text { Spec. number } \\
\text { locality } \\
\text { sampling location }\end{array}$ & Length & Medulla & (Pre-)htb & $\begin{array}{l}\text { Gm } \\
\text { count/ } \\
\text { onset sm }\end{array}$ & $\mathrm{Bc}$ & Comment \\
\hline \multicolumn{7}{|l|}{ Germanic Basin } \\
\hline \multicolumn{7}{|c|}{$\begin{array}{l}\text { Early Anisian } \\
\text { (Lower Muschelkalk) }\end{array}$} \\
\hline \multicolumn{7}{|c|}{ Dactylosaurus from Poland } \\
\hline $\begin{array}{l}\text { MB.R. } 771.5 \\
\text { midshaft }\end{array}$ & 2.08 & $\begin{array}{l}\text { small med. reg. with } \\
\text { a free cav. lined by eb }\end{array}$ & $\begin{array}{l}\text { ring of (pre-)htb } \\
\text { (slow growth) }\end{array}$ & $\begin{array}{l}10 / 6 \\
2 / 1\end{array}$ & $95.5 \%$ & \\
\hline $\begin{array}{l}\text { MB.R. } 776.3 \\
\text { midshaft }\end{array}$ & 2.16 & $\begin{array}{l}\text { small med. reg. with } \\
\text { a free cav. lined by eb }\end{array}$ & $\begin{array}{l}\text { ring of (pre-)htb } \\
\text { (slow growth) }\end{array}$ & $\begin{array}{l}1 / 1 \\
(2 \mathrm{sc})\end{array}$ & $93.5 \%$ & \\
\hline $\begin{array}{l}\text { MB.R. } 801.1 \\
\text { distal to midshaft }\end{array}$ & 2.27 & $\begin{array}{l}\text { large med. reg, cc, } \\
\text { eb, ec, sl }\end{array}$ & & $2 / 1$ & $91 \%$ & \\
\hline $\begin{array}{l}\text { MB.R. } 801.2 \\
\text { distal to midshaft }\end{array}$ & 2.4 & $\begin{array}{l}\text { large med. reg, cc, } \\
\text { eb, ec, sl }\end{array}$ & & $4 / 2$ & $93.7 \%$ & \\
\hline $\begin{array}{l}\text { MB.R. } 772.3 \\
\text { midshaft }\end{array}$ & 2.73 & $\begin{array}{l}\text { small med. reg. with } \\
\text { a free cav. lined by eb }\end{array}$ & $\begin{array}{l}\text { remains of (pre-)htb } \\
\text { (fast growth) }\end{array}$ & $5 / 2$ & $89.6 \%$ & \\
\hline $\begin{array}{l}\text { MB.R. } 776.2 \\
\text { distal to midshaft }\end{array}$ & 3.82 & $\begin{array}{l}\text { small med. reg. with } \\
\text { a free cav. lined by eb }\end{array}$ & $\begin{array}{l}\text { remains of (pre-)htb } \\
\text { (fast growth) }\end{array}$ & $5 / 1$ or 2 & $92.4 \%$ & $\begin{array}{l}\text { layer of perpendicularly } \\
\text { oriented fine fibers around } \\
\text { the (pre-)htb }\end{array}$ \\
\hline $\begin{array}{l}\text { MB.R. } 786 \\
\text { distal to midshaft }\end{array}$ & 4.4 & large med. reg., cc, sl & & $9 / 1$ & $92.9 \%$ & \\
\hline \multicolumn{7}{|c|}{$\begin{array}{l}\text { Middle Anisian } \\
\text { (Lower Muschelkalk) }\end{array}$} \\
\hline \multicolumn{7}{|c|}{ Anarosaurus from Winterswijk } \\
\hline $\begin{array}{l}\text { Wijk06-238 } \\
\text { midshaft }\end{array}$ & $>2.0$ & free cav. & $\begin{array}{l}\text { remains of (pre-)htb } \\
\text { (fast growth) }\end{array}$ & 0 & $79.8 \%$ & \\
\hline $\begin{array}{l}\text { Wijk13-194 } \\
\text { midshaft }\end{array}$ & 2.95 & free cav. lined by eb & $\begin{array}{l}\text { ring of (pre-)htb } \\
\text { (fast growth sur- } \\
\text { rounded by gm) }\end{array}$ & 1 & $79.5 \%$ & \\
\hline $\begin{array}{l}\text { Wijk07-137 } \\
\text { midshaft }\end{array}$ & $\sim 3.0$ & free cav. lined by eb & & 2 & $66.8 \%$ & \\
\hline $\begin{array}{l}\text { Wijk08-219 } \\
\text { midshaft }\end{array}$ & 3.4 & free cav. lined by eb & $\begin{array}{l}\text { remains of (pre-)htb } \\
\text { (slow growth) }\end{array}$ & 1 & $79 \%$ & \\
\hline $\begin{array}{l}\text { TWE } 320 \\
\text { midshaft }\end{array}$ & $\sim 3.5$ & free cav. lined by eb & ring of (pre-)htb & 4 & $82.9 \%$ & \\
\hline $\begin{array}{l}\text { Wijk09-543 } \\
\text { midshaft }\end{array}$ & 3.6 & free cav. lined by eb & $\begin{array}{l}\text { remains of (pre-)htb } \\
\text { (slow growth) }\end{array}$ & 2 & $89.2 \%$ & \\
\hline $\begin{array}{l}\text { Wijk07-50 } \\
\text { midshaft }\end{array}$ & 4.15 & free cav. lined by eb & $\begin{array}{l}\text { ring of (pre-)htb } \\
\text { (fast growth sur- } \\
\text { rounded by gm) }\end{array}$ & 5 & $78.9 \%$ & \\
\hline $\begin{array}{l}\text { Wijk07-70 } \\
\text { midshaft }\end{array}$ & $\sim 4.4$ & free cav. lined by eb & $\begin{array}{l}\text { remains of (pre-)htb } \\
\text { (fast growth) }\end{array}$ & 4 & $77.2 \%$ & \\
\hline $\begin{array}{l}\text { Wijk09-472 } \\
\text { midshaft }\end{array}$ & 4.35 & free cav. lined by eb & $\begin{array}{l}\text { remains of (pre-) htb } \\
\text { (slow growth) }\end{array}$ & 6 & $88.6 \%$ & \\
\hline $\begin{array}{l}\text { Wijk09-58 } \\
\text { midshaft }\end{array}$ & 4.9 & free cav. lined by eb & remains of (pre-)htb & 6 & $85.4 \%$ & \\
\hline $\begin{array}{l}\text { Wijk08-183 } \\
\text { midshaft }\end{array}$ & 5.05 & free cav. lined by eb & $\begin{array}{l}\text { remains of (pre-)htb } \\
\text { (slow growth) }\end{array}$ & 4 & $78.7 \%$ & \\
\hline
\end{tabular}


Table 1. Continued.

\begin{tabular}{|c|c|c|c|c|c|c|}
\hline $\begin{array}{l}\text { Spec. number } \\
\text { locality } \\
\text { sampling Location }\end{array}$ & Length & Medulla & (Pre-)Htb & $\begin{array}{l}\text { Gm } \\
\text { count/ } \\
\text { onset sm }\end{array}$ & $\mathrm{BC}$ & Comment \\
\hline \multicolumn{7}{|l|}{$\begin{array}{l}\text { Late Ladinian } \\
\text { (Lower Keuper) }\end{array}$} \\
\hline \multicolumn{7}{|c|}{ aff. Neusticosaurus pusillus from southern Germany } \\
\hline $\begin{array}{l}\text { SMNS 58025-1 } \\
\text { midshaft }\end{array}$ & 1.305 & eb, large er cav. & remains of (pre-)htb & 0 & $86.3 \%$ & \\
\hline $\begin{array}{l}\text { SMNS 58025-2 } \\
\text { midshaft }\end{array}$ & 1.43 & eb, large er cav. & remains of (pre-)htb & $2 / 1$ & $92.7 \%$ & $\begin{array}{l}\text { layer of perpendicularly } \\
\text { oriented fine fibers around } \\
\text { the (pre-)htb }\end{array}$ \\
\hline $\begin{array}{l}\text { SMNS 50372a } \\
\text { distal to midshaft }\end{array}$ & 1.7 & $\begin{array}{l}\text { large cav. lined by eb, } \\
\text { cc at margin, sl }\end{array}$ & remains of (pre-)htb & $2 / 1$ & $86.8 \%$ & \\
\hline $\begin{array}{l}\text { SMNS } 50372 b \\
\text { midshaft }\end{array}$ & 1.7 & eb filled med. reg. & $\begin{array}{l}\text { remains of (pre-)htb } \\
\text { (fast growth sur- } \\
\text { rounded by a growth } \\
\text { mark) }\end{array}$ & $3 / 1$ or 2 & $91.6 \%$ & $\begin{array}{l}\text { layer of perpendicularly } \\
\text { oriented fine fibers around } \\
\text { the (pre-)htb; } \\
\text { sheathed primary osteons }\end{array}$ \\
\hline $\begin{array}{l}\text { SMNS } 50372 \mathrm{c} \\
\text { midshaft }\end{array}$ & 1.715 & $\begin{array}{l}\text { eb filled med. reg. } \\
\text { with few ec }\end{array}$ & $\begin{array}{l}\text { remains of (pre-)htb } \\
\text { (fast growth } \\
\text { surrounded by a } \\
\text { growth mark) }\end{array}$ & $7 / 2$ & $88.6 \%$ & $\begin{array}{l}\text { layer of perpendicularly } \\
\text { oriented fine fibers around } \\
\text { the (pre-)htb }\end{array}$ \\
\hline $\begin{array}{l}\text { SMNS } 92125 \\
\text { distal to midshaft }\end{array}$ & 1.81 & $\begin{array}{l}\text { free cav., lined by eb, } \\
\text { cc, sl }\end{array}$ & $\begin{array}{l}\text { remains of (pre-)htb } \\
\text { (slow growth } \\
\text { surrounded by a } \\
\text { growth mark) }\end{array}$ & $6 / 1$ & $95.6 \%$ & $\begin{array}{l}\text { layer of perpendicularly } \\
\text { oriented fine fibers around } \\
\text { the (pre-)htb }\end{array}$ \\
\hline $\begin{array}{l}\text { SMNS } 56312 \\
\text { midshaft }\end{array}$ & 2.48 & free cav. eb filled & remains of (pre-)htb & $3 / 2$ & $88 \%$ & \\
\hline \multicolumn{7}{|c|}{ Alpine Triassic/Monte San Giorgio } \\
\hline \multicolumn{7}{|l|}{ Ladinian } \\
\hline \multicolumn{7}{|l|}{ N. pusillus } \\
\hline $\begin{array}{l}\text { PIMUZ T } 4178 \\
\text { midshaft }\end{array}$ & $\sim 1.75$ & eb, er cav. & & $7 / 2$ & $x$ & $\begin{array}{l}\text { sm is interpreted after an- } \\
\text { other gm than in Hugi et al. } \\
\text { (2011) }\end{array}$ \\
\hline $\begin{array}{l}\text { PIMUZ T } 4211 \\
\text { proximal }\end{array}$ & $\sim 1.65$ & $\mathrm{eb}, \mathrm{cc}$, round ec & & $6 / 2$ & $\times$ & \\
\hline \multicolumn{7}{|l|}{ N. edwardsii } \\
\hline $\begin{array}{l}\text { PIMUZ phz } 153 \\
\text { midshaft }\end{array}$ & 3.97 & small free cav. & & $8 / ?$ & $x$ & \\
\hline $\begin{array}{l}\text { PIMUZ T } 4758 \\
\text { midshaft }\end{array}$ & 2.87 & eb filled med. reg. & & $5 / ?$ & $x$ & \\
\hline \multicolumn{7}{|l|}{ Serpianosaurus } \\
\hline $\begin{array}{l}\text { PIMUZ phz } 119 \\
\text { midshaft }\end{array}$ & 2.13 & $\begin{array}{l}\text { small free cav. } \\
\text { lined by eb }\end{array}$ & & $8 / ?$ & $x$ & \\
\hline $\begin{array}{l}\text { PIMUZ T } 4510 \\
\text { midshaft }\end{array}$ & 3.0 & eb filled med. reg. & & $11 / ?$ & $x$ & \\
\hline
\end{tabular}


lows Francillon-Vieillot et al. (1990). Annual growth cycles were marked with Adobe Photoshop CS5.1. Before being digitally traced, their position was always double-checked in the original thin section in both normal and polarized light. Due to the lack of remodeling, reconstruction of lost inner growth marks was not necessary, except for humeri PIMUZ T 4211 (N. pusillus), PIMUZ T 4510, and PIMUZ T 119 (both Serpianosaurus), which were finally passed to growth curve modeling and presumably were not cut exactly at the midshaft. Bone compactness was measured with a custom-designed pixel counting computer program (P. Göddertz, StIPB(C). Our method of body mass reconstruction is described in detail in the Supplement S1.

\subsubsection{Modeling growth, estimation of life-history traits, and birth to adult length ratios}

From our total sample of 31 pachypleurosaur specimens (Table 1), we first chose 17 specimens that have preserved five growth marks or at least four growth marks and the outer cortex. Only these specimens were passed to growth curve modeling (Dactylosaurus: MB.R. 771.5, MB.R. 801.2, MB.R. 772.3, MB.R. 776.2, MB.R. 786; Anarosaurus: Wijk0750, Wijk07-70, Wijk09-472, Wijk09-58; aff. Neusticosaurus pusillus: SMNS 50372c, SMNS 92125; N. pusillus: PIMUZ T 4178, PIMUZ T 4211; N. edwardsii: PIMUZ phz 153, PIMUZ T 4758; Serpianosaurus: PIMUZ phz 119, PIMUZ $\mathrm{T}$ 4510). The number of growth marks should preferably be as high as possible for growth curve modeling to cover more than just the quasi-linear phase of growth (Klein and Griebeler, 2016; see below). We then carried out a complex model fitting procedure for each of these specimens in order to find the statistically best growth model(s) for each of them. The complete fitting procedure is described in detail in Supplement S2. Here we give only a rough outline of the procedure. Our procedure is based on Griebeler et al. (2013) and was already improved in Klein et al. (2015b) and Klein and Griebeler (2016). It is also able to tackle the technical problem that an unknown number of growth marks could be missing from the inner part of a bone. An estimation of this number had to be done for 3 out of the 17 specimens modeled (aff. Neusticosaurus pusillus: PIMUZ T 4211; Serpianosaurus: PIMUZ phz 119, PIMUZ T 4510). For all others there was no histological indication that growth marks are lost in the inner part of the cortex (Table 1). Our procedure also explicitly tackles the technical problem, which is that the growth record has no information preserved on both growth acceleration and deceleration; i.e., the record covers only the exponential, quasi-linear or asymptotic phase of growth (see discussion in Myhrvold, 2013). This information on growth is needed for establishing a reliable sigmoidal growth model on a specimen (Myhrvold, 2013; Klein et al., 2015b; Klein and Griebeler, 2016). This criterion finally failed for 4 out of the 17 specimens passed to modeling. Their growth record clearly covered only the quasi-linear phase of growth. Thus, we were finally able to establish growth model(s) for 13 pachypleurosaurs.

All models tested for pachypleurosaurs relate humerus length $(\mathrm{cm})$ to age (years), because mass estimation is difficult in Pachypleurosauria (see Supplement S1) and would make our growth models less precise. We always considered four standard growth models for each specimen: von Bertalanffy (vBGM), Gompertz (GGM), logistic (LGM), and Chapman-Richards (CRGM). These standard growth models differ in the masses at which the increase in humerus length is maximal (i.e., inflection point). However, finally the CRGM could not be fitted to the growth record of any specimen studied so far (see also Klein et al., 2015b; Klein and Griebeler, 2016), presumably because of its large number of parameters that have to be estimated.

The specific equations used for the vBGM (Eq. 1), GGM (Eq. 2), and LGM (Eq. 3) (Klein et al., 2015b; Klein and Griebeler, 2016) are as follows:

$$
\begin{aligned}
& L(t)=L_{\max }-\left(L_{\max }-L_{0}\right) \exp (-g t), \\
& L(t)=L_{0}+L_{\max } \exp (-\exp (-g(t-i))), \\
& L(t)=L_{0}+\frac{L_{\max }}{1+\exp (-g(t-i))} .
\end{aligned}
$$

In Eqs. (1) through (3), $L(t)$ is length at age $t$ (where $t$ is a real number), $L_{0}$ is an initial length, $L_{\max }$ is the maximum length, $g$ the growth parameter, and $i$ the location of the inflection point on the age axis. Please note that our formulation of the GGM and LGM allows a flexible location of the inflection point with respect to age (contrary to the other formulations of both models). Note also that only under the vBGM (formulation taken from von Bertalanffy, 1938, 1957; Pütter, 1920) the humerus length at age 0 (birth size) is $L_{0}$ and asymptotic length equals $L_{\max }$. By contrast, for the GGM and LGM humerus length at age 0 (birth size) is $L(t)$ evaluated at $t=0(=L(0))$ and asymptotic length is $L_{0}+L_{\text {max }}$. Under the GGM and LGM parameter $L_{0}$ allows for a non-zero length at $t=0$ and thus it moves the respective growth curve along the length axis.

Before applying any standard growth model to each specimen, we tested whether its growth record covers only the exponential, quasi-linear or asymptotic phase of growth (Myhrvold, 2013). We therefore fitted an exponential (Eq. 4), linear (Eq. 5) and asymptotic equation (Eq. 6) to its ontogenetic growth series on humerus length (Klein et al., 2015b; Klein and Griebeler, 2016):

$L(t)=L_{0} \exp (g t)$,
$L(t)=L_{0}+g t$,
$L(t)=L_{0}+\left(L_{\text {death }}-L_{0}\right)(1-\exp (-g t))$.

In Eqs. (4) through (6) $L_{0}$ is humerus length preserved at the first growth mark $(t=0)$, and $g$ the growth parameter. In Eq. (6) $L_{\text {death }}$ is length at the last growth mark preserved or observed for the outer cortex. Equation (1) on the vBGM has 
three parameters $\left(L_{0}, L_{\max }, g\right)$ and Eqs. (2) and (3), on the GGM and LGM, respectively, have four $\left(L_{0}, L_{\max }, g, i\right)$, and that on the CRGM has five. These high numbers of parameters can become problematic in non-linear regression analysis and statistics of estimated parameters when the number of growth marks preserved in a bone is comparatively small. This is true for the majority of specimens studied herein. We therefore additionally considered simpler equations for each of the standard growth models (Eqs. 1 through 3), in which we fixed different model parameters to specific values (i.e., did not fit them, for details on this refer to Supplement S2). Thus, finally, 6 equations derived from the general equation were applied to each specimen implementing von Bertalanffy growth (Eq. 1), 11 equations implementing Gompertz growth (Eq. 2), 11 equations implementing logistic growth (Eq. 3), and 12 equations implementing Chapman-Richards growth. Thus, in total for each of the specimens under study we considered 40 equations on standard growth models and 3 equations testing whether not only one phase of growth is preserved in its growth record (exponential, quasi-linear, or asymptotic, Eqs. 4 through 6). To derive the best number of missing growth marks and the best birth size for the three humeri PIMUZ T 4211 (N. pusillus), PIMUZ T 4510, and PIMUZ T 119 (both Serpianosaurus), 40 growth equations were applied. In addition, we did a manual grid search on numbers of missing growth marks and birth sizes (for more details on this procedure refer to Supplement S2).

Out of all growth model equations applied to a specimen we next identified those being statistically assured (i.e., all model parameter estimates differ significantly from zero; for more details refer to the Supplement S2) and which of these models were also biologically reliable (e.g., $L_{\text {birth }}$ is not negative, inflection point is located after the birth of the individual). From the models passing all criteria, we identified the statistical best model(s) out of these for each specimen by using an Akaike information criterion (AIC) based approach (Burnham and Anderson, 2002, AIC corrected for small sample sizes, the best models are within the range $\Delta \mathrm{AIC} \leq 10$, Griebeler et al., 2013; Klein et al., 2015b; Klein and Griebeler, 2016; for more details on this model selection process refer to Supplement S2).

We calculated for each specimen five life-history traits from each of its best growth curves (those passing the $\Delta \mathrm{AIC} \leq 10$ criterion): humerus length at birth ( $\left.L_{\text {birth }}\right)$, asymptotic humerus length (AL), age at which sexual maturity is reached (ASM), humerus length of a fully grown individual (99\% AL; equals $99 \%$ of AL), and age at which the individual is fully grown (AA; age at which $99 \%$ of AL is reached). To estimate the age at which the individual reached sexual maturity from its growth curve (ASM), we assumed that the inflection point of the curve coincides with sexual maturation. Evidence for this concept exists in reptiles and amphibians (Kupfer et al., 2004; Lee and Werning, 2008; Reiss, 1989; Ritz et al., 2010). Under the GGM, ASM is seen at about $38 \%$ of AL and under the LGM at $50 \%$ of AL. As our formulation of the vBGM (Eq. 1) only has an inflection point when mass is plotted against age (at $30 \%$ of asymptotic mass), we assumed that ASM coincides with the age at which $30 \%$ of AL is reached (Klein et al., 2015b).

To the growth record of Anarosaurus Wijk07-70 and $N$. edwardsii PIMUZ T 4758 the single best growth model was finally identified. We calculated AL, ASM, 99\% AL, and AA directly from the respective curve. To find estimates on $L_{\text {birth }}$ AL, ASM, $99 \%$ AL, and AA for specimens for which more than one growth model worked well, we did model averaging for trait values (Burnham and Anderson, 2002). We therefore first estimated each of these five traits from all of its best growth curves. We then averaged these values based on the models' respective Akaike weights for each of the traits (Burnham and Anderson, 2002).

Maximum growth rate (MGR) was also obtained from model averaging, except for Wijk07-70 and PIMUZ T 4758. We therefore estimated the annual mass gain seen within the year of the inflection point (ages $i$, and $i+1$ ), and calculated body masses from humerus length at age $i$ and $(i+1)$ for each of the best models on the specimen's growth record.

Estimated birth to adult size ratios ( $L_{\text {birth }}$ ToAL) of specimens were derived from averaged $L_{\text {birth }}$ and $99 \%$ AL values, again except for Wijk07-70 and PIMUZ T 4758.

\section{Results}

\subsection{Histological description}

\subsubsection{Microanatomy of Dactylosaurus and aff. $N$. pusillus}

All humeral cross sections are round-oval at midshaft and more oval or elliptical towards the proximal and distal end. All samples, proximally or distally to midshaft, display a medullary region that consists of a matrix of calcified cartilage that contains some small round erosion cavities surrounded by endosteal bone (Fig. 1b). The medullary region is here surrounded by a sharp line (Fig. 1a; Table 1), which separates the periosteal from the endosteal domain. In samples close to midshaft, the amount of calcified cartilage is low and often only locally visible at the inner margin of the sharp line. At midshaft, no calcified cartilage is preserved (Fig. 1c).

Midshaft samples of Dactylosaurus have a small medullary region consisting of a small, round, and well delimited free cavity that is surrounded by endosteal bone (Fig. 1d). Bone compactness is in Dactylosaurus between 89.6 and $95.5 \%$ (Table 1 ).

The medullary region in samples of aff. $N$. pusillus is more variable but the medullary region is also always small. SMNS 58025a and SMNS 58025b display little endosteal bone and several large, irregularly formed erosion cavities that reach into the periosteal domain (i.e., indicating some remodeling) (Fig. 1e). SMNS 50372a and SMNS 92125 were not sampled 



Figure 1. Details of medulla, bone tissue, and vascularization of Dactylosaurus from the early Anisian (Lower Muschelkalk; Germanic Basin) and aff. N. pusillus from the late Ladinian (Lower Keuper; Germanic Basin). (a) Medullary region distally to midshaft in Dactylosaurus humerus MB.R. 801.2. consisting of small round erosion cavities surrounded by endosteal bone and embedded in a matrix of calcified cartilage. The medullary region is surrounded by a sharp line (arrow). (b) Medullary region closer to midshaft in Dactylosaurus humerus MB.R. 771.5 displaying a small free cavity, a few small erosion cavities surrounded by endosteal bone and calcified cartilage at the border to the periosteal region all encompassed by a sharp line (arrow). Around the medullary cavity slow-deposited (i.e., highly organized) hatchling bone tissue is visible. (c) The medullary region and inner cortex in aff. N. pusillus humerus SMNS 50372b is nearly completely filled by endosteal bone. The area is surrounded by the sharp line (arrow), although the sample was taken nearly at the midshaft. Scattered longitudinal primary osteons occur in this sample. (d) Cross section of aff. N. pusillus humerus SMNS 58025a which shows an irregular medullary region and remodeling in form of erosion cavities scattered into the periosteal bone. (e) Medullary region and inner cortex of aff. N. pusillus humerus SMNS 50372c. The medullary region consists of few small erosion cavities and endosteal bone. The innermost cortex is made of fast-deposited hatchling bone tissue, which is surrounded by a distinct annulus. (f) Medullary region and inner cortex of aff. N. pusillus humerus SMNS 92125. The medullary region consists of a small cavity surrounded by a thick layer of endosteal bone, which are encompassed by a sharp line and calcified cartilage. The innermost cortex is made of a slow-deposited hatchling bone tissue. (g) Cross section of N. pusillus humerus PIMUZ T 3975. The medullary region is completely filled by endosteal bone. The area is surrounded by some erosion cavities. (h) Medullary region and inner cortex at midshaft in Dactylosaurus humerus MB.R. 776.2 showing a free cavity surrounded by a thick layer of endosteal bone. On the right side are remains of preserved fast-deposited (i.e., less organized) hatchling bone tissue. On the right side, the layer of horizontally oriented fine fibers is visible (arrow). (i) Medullary region and inner cortex in Anarosaurus humerus Wijk 13-194. The relatively large, free medullary cavity is surrounded by a thin, and in this sample incomplete, layer of endosteal bone. The innermost cortex is made of a fast-deposited (i.e., highly organized) hatchling bone tissue, which is surrounded by a distinct annulus. A second annulus is clearly visible in the lower part of the picture. Distance between annuli changes considerably towards the preaxial bone side (arrows mark spilt). Abbreviations: cc, calcified cartilage; eb, endosteal bone; ec, erosion cavity; htb, hatchling bone tissue; ffho, fine fibers horizontally oriented; mc, medullary cavity; mr, medullary region; po, primary osteon. All pictures are in polarized light. Scale bar is $0.5 \mathrm{~mm}$ if not labeled otherwise.

Foss. Rec., 21, 137-157, 2018 
exactly at midshaft and have both a free cavity surrounded by thick endosteal bone, calcified cartilage, and a sharp line. SMNS 50372b displays a central free cavity surrounded by endosteal bone (Fig. 1f) whereas in SMNS 50372c few small erosion cavities and in SMNS 56312 few round decentral cavities are documented (Fig. 1g). In SMNS 50372a, b, and $\mathrm{c}$ the cavity of the nutrient foramen is visible. Bone compactness is in samples of aff. $N$. pusillus between 86.3 and $95.6 \%$.

\subsubsection{Bone tissue and vascularization of Dactylosaurus and aff. $N$. pusillus}

Bone tissue in Dactylosaurus and aff. N. pusillus is dominated by parallel-fibered bone with an increase of highly organized tissue towards the outer cortex. Some samples have woven bone deposited in the inner cortex. Please note that we follow the definition of Francillon-Vieillot et al. (1990: 206) for woven bone but see Stein and Prondvai (2013) for more information on the problem of identifying true woven bone tissue. The bone tissue type can be summarized as lamellarzonal bone. Midshaft samples of Dactylosaurus and aff. $N$. pusillus have a loosely organized bone tissue (woven bone and/or loosely organized parallel-fibered bone) preserved in their innermost cortex, which we interpret as (pre-)hatchling bone tissue (Fig. 1; Table 1). In some samples this tissue is surrounded by a distinct layer formed by highly organized, and perpendicularly oriented fine fibers (Figs. 1h, 2e). The tissue appears very bright in normal light and shows the extinction pattern of lamellar bone in polarized light. Only one humerus of Dactylosaurus (MB.R. 776.2) but several humeri of aff. N. pusillus (SMNS 58025-2, SMNS 50372b, c, SMNS 92125) show this distinct layer of highly organized and perpendicularly oriented fine fibers around the (pre-)hatchling tissue (Table 1).

Vascularization is dominated by radial vascular canals but longitudinal canals also occur (Figs. 1, 2). Some vascular canals are lined by lamellar bone and thus started being transformed into primary osteons. Some samples show a funnelshaped arrangement of the crystallites around the simple, mainly radial vascular canals, which may be a precursor of an alignment by lamellar bone of true primary osteons. Vascular density is low, although in some samples long radial vascular canals occur that reach over several growth layers and open into the outer surface (Fig. 1d). One aff. N. pusillus humerus (SMNS 50372b) has longitudinal primary osteons developed, which are well sheathed by lamellar bone (Fig. 1c). These primary osteons are similar to what was described for some placodonts (Klein et al., 2015a, b).

\subsubsection{Growth record of Dactylosaurus and aff. $N$. pusillus}

Growth marks occur in form of zones, annuli, and LAGs (lines of arrested growth). Subcycles, in the form of thin layers of highly organized bone tissue, which cannot be followed all around the cross section, are common as well. Histological onset of sexual maturation (Table 1) was estimated on the basis of the clearest growth mark in the inner or middle cortex, accompanied by a general increase in bone tissue organization in the following cycles. Midshaft samples of Dactylosaurus and aff. $N$. pusillus display an inner ring of (pre-)hatchling bone, implying that the growth record is complete. However, this inner tissue is not separated by an annual growth mark. Some samples show distinct LAGs well visible in normal light, whereas others display a more diffuse growth pattern, consisting of alternating zones and annuli, best visible in polarized light. In some humeri, the inner tissue is made of a bone tissue suggesting very fast growth (woven bone, loosely organized parallel-fibered bone, and high vascular density) whereas others have here a tissue suggesting slow growth (highly organized parallel-fibered bone and low vascular density).

\subsection{Comparison of microanatomy, bone tissue, and vascularization}

All pachypleurosaurs (Anarosaurus, Dactylosaurus, Neusticosaurus spp., Serpianosaurus) share the same inner structure of the medullary region of non-midshaft samples (i.e., calcified cartilage, erosion cavities, endosteal bone, and sharp line). At midshaft, the medulla varies. Anarosaurus is the only pachypleurosaur in the sample that has a large medullary cavity, which is a plesiomorphic feature considering the condition in terrestrial reptiles (Canoville and Laurin, 2010). When a medullary cavity is present, it is usually very small in Dactylosaurus and aff. N. pusillus (Table 1; Fig. 1). The small size of the medullary cavity is the result of a filling of the cavity by endosteal bone, resulting in bone mass increase or osteosclerosis. Pachypleurosaurs from the Alpine Triassic also display bone mass increase. They either have a very small cavity surrounded by a thick layer of endosteal bone, a medullary region filled with endosteal bone, or a medullary region that is filled by endosteal bone and small erosion cavities at its border (Hugi et al., 2011). In Anarosaurus, the large medullary cavity is lined by a thin layer of endosteal bone (except for the smallest humerus Wijk06-238) but no filling up of the cavity is documented. The retainment of a large medullary cavity throughout ontogeny results in a decrease in bone mass and the lowest bone compactness values among pachypleurosaurs (i.e., between 89.9 and $66.8 \%$ ) in Anarosaurus. For comparison, bone compactness is between 95.5 and $89.6 \%$ in Dactylosaurus, between 95.6 and $84.7 \%$ in aff. N. pusillus from southern Germany, and is always over $90 \%$, usually even 

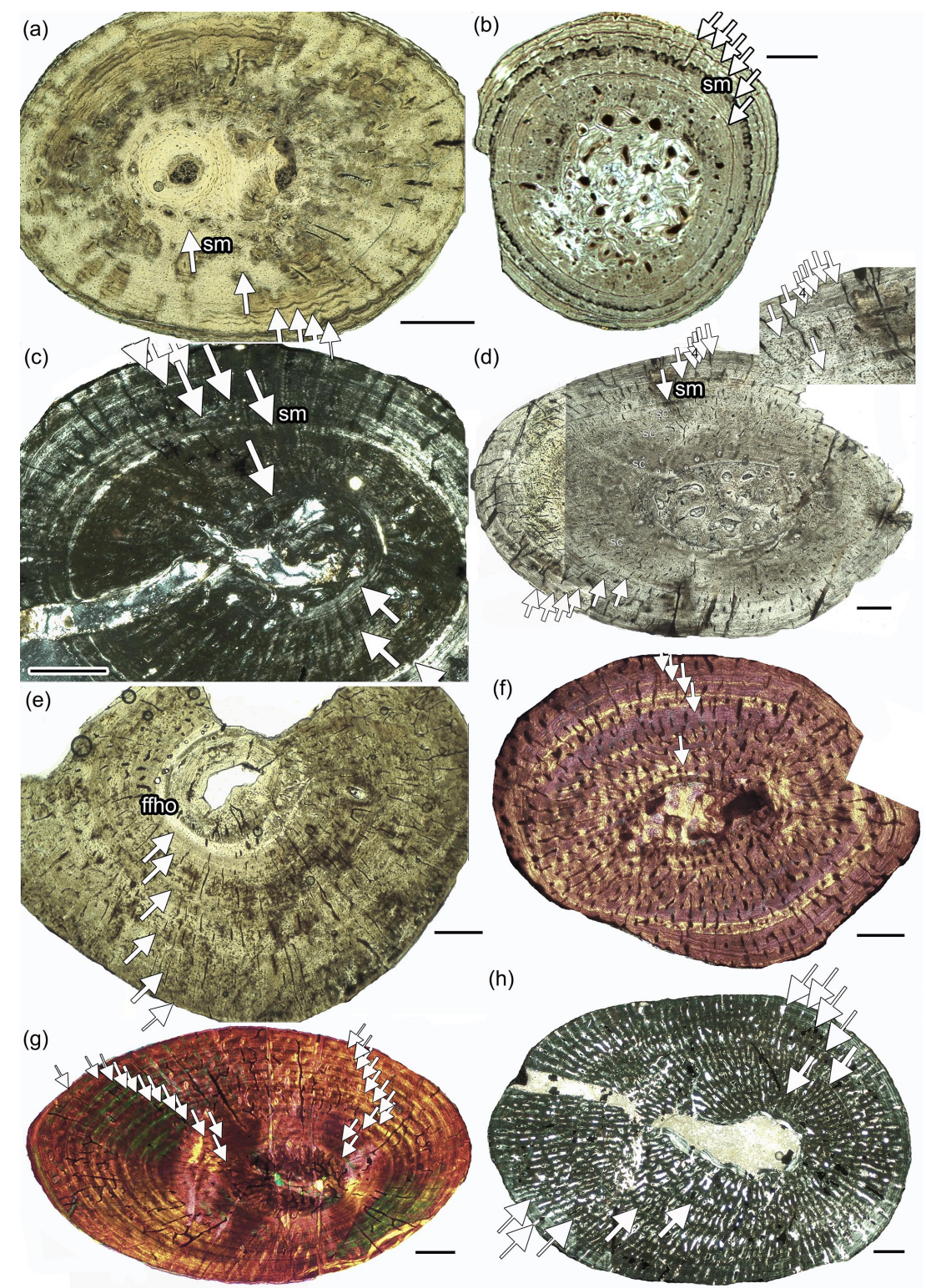

Figure 2. Growth record in Dactylosaurus from the Germanic Basin (Lower Muschelkalk, early Anisian), in aff. N. pusillus from the Germanic Basin (Lower Keuper, late Ladinian) and in Neusticosaurus spp. and in Serpianosaurus from the Alpine Triassic (Anisian/Ladinian). (a) aff. N. pusillus SMNS 92125. (b) N. pusillus PIMUZ T 4211. (c) aff. N. pusillus SMNS 50372c. (d) Dactylosaurus MB.R.786. (e) Dactylosaurus MB.R. 776.2. (f) N. edwardsii PIMUZ T4758. (g) Serpianosaurus PIMUZ T 4510. (h) Wijk 09-472. Abbreviations: sc, subcycles; sm, sexual maturity. Panels $(\mathbf{a}, \mathbf{b}, \mathbf{d}, \mathbf{e})$ are in normal light, $(\mathbf{c}, \mathbf{h})$ are in polarized light, and (f, $\mathbf{g})$ are in polarized light with gypsum filter (lambda). Scale bar is $0.5 \mathrm{~mm}$.

over $95 \%$ in pachypleurosaurs from the Alpine Triassic (Table 1; Hugi et al., 2011), clearly documenting bone mass increase (i.e., osteosclerosis) in these taxa.

In all pachypleurosaurs vascularization is dominated by longitudinal and radial vascular canals. Vascular density is highest in Anarosaurus and considerably lower in the other pachypleurosaurs.

Bone tissue of Dactylosaurus, Neusticosaurus spp., and Serpianosaurus can be summarized as lamellar-zonal bone.
Also, contrary to the other pachypleurosaurs, the bone tissue type of Anarosaurus is summarized as incipient fibrolamellar bone (Klein, 2010), and indicates a higher growth rate than the other taxa show. Some remodeling of the inner cortex in the form of scattered erosion cavities can occur in taxa of the Neusticosaurus-Serpianosaurus clade. 


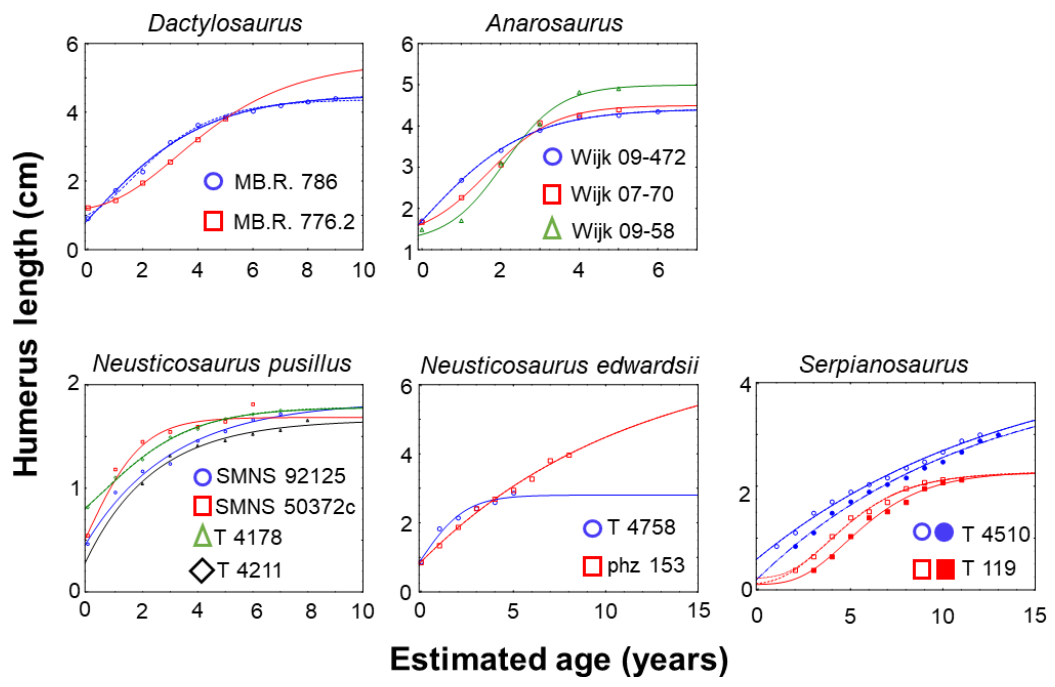

Figure 3. Growth record and established growth models for pachypleurosaurs. The statistically best growth models are shown for each specimen. These have the highest Akaike weights (Burnham and Anderson, 2002) compared to the others which were also applicable to the growth record of the specific specimen (see Table S1). Specimens are marked by colors. Growth curves on the same specimen are marked by different line types (solid, dotted) in equal color. Parameter values of models and fitting statistics are summarized in Table S1. Neusticosaurus pusillus specimens SMNS 92125 and SMNS 50372c are from the Germanic Basin (aff. N. pusillus), and specimens PIMUZ T 4178 and PIMUZ T 4211 are from the Alpine Triassic.

Table 2. Life-history traits and birth-to-adult length ratios derived from best growth models established for specimens. For 2 out of the 13 specimens one standard growth model was clearly statistically supported, whereas for the other specimens at least two models fitted similar well in terms of AIC. Abbreviations: $\mathrm{bl}=$ bone length, see Table 1; mass = mass of the specimen estimated from bl, see Supplement S1; $\mathrm{bl}_{1 \mathrm{gm}}=$ bone length corresponding to the first growth mark preserved; model: LGM $=$ logistic growth model, average $=$ values of lifehistory traits and ratios are averages calculated based on the respective Akaike weights of their best growth models; $L_{\text {birth }}=$ bone length at birth; $\mathrm{AL}=$ asymptotic bone length; $\mathrm{ASM}=$ age at which sexual maturity is reached; \%99AL $=99 \%$ of $\mathrm{AL} ; \mathrm{AA}=$ asymptotic age, estimated as age at which $99 \%$ of $\mathrm{AL}$ is reached; $\mathrm{AD}=$ age at death; $L_{\text {birth }}$ ToAL $=$ ratio of birth and asymptotic length; $L_{1 \mathrm{gm}} \mathrm{To}_{\mathrm{death}}=\mathrm{bl} \mathrm{gm}_{1 \mathrm{gm}} / \mathrm{bl}$; MGR $=$ maximum growth rate, growth rate increment seen in the year of ASM (inflection point).

\begin{tabular}{|c|c|c|c|c|c|c|c|c|c|c|c|c|c|c|}
\hline & Bone spec. no. & $\begin{array}{r}\mathrm{bl} \\
(\mathrm{cm})\end{array}$ & $\begin{array}{r}\text { mass } \\
(\mathrm{g})\end{array}$ & $\begin{array}{r}\mathrm{bl}_{1 \mathrm{gm}} \\
(\mathrm{cm})\end{array}$ & model & $\begin{array}{r}L_{\text {birth }} \\
(\mathrm{cm})\end{array}$ & $\begin{array}{r}\mathrm{AL} \\
(\mathrm{cm})\end{array}$ & $\begin{array}{r}\text { ASM } \\
\text { (years) }\end{array}$ & $\begin{array}{r}99 \% \mathrm{AL} \\
(\mathrm{cm})\end{array}$ & $\begin{array}{r}\text { AA } \\
\text { (years) }\end{array}$ & $\begin{array}{r}\mathrm{AD} \\
\text { (years) }\end{array}$ & $\begin{array}{r}L_{\text {birth }} \text { To } \\
\text { AL }\end{array}$ & $\begin{array}{r}L_{1 \mathrm{gm}} \text { To } \\
L_{\text {death }}\end{array}$ & $\begin{array}{r}\text { MGR } \\
\left(\mathrm{g} \mathrm{day}^{-1}\right)\end{array}$ \\
\hline \multirow[t]{2}{*}{ Dactylosaurus } & MB.R. 786 & 4.400 & 1239 & 0.970 & average & 0.913 & 4.479 & 1.476 & 4.434 & 9.149 & 9 & 0.220 & 0.208 & 0.672 \\
\hline & MB.R. 776.2 & 3.820 & 1075 & 1.216 & average & 1.210 & 5.444 & 3.236 & 5.390 & 13.548 & 5 & 0.222 & 0.318 & 0.882 \\
\hline \multirow[t]{3}{*}{ Anarosaurus } & Wijk 09-472 & 4.350 & 2175 & 1.704 & average & 1.706 & 4.409 & 0.351 & 4.365 & 6.331 & 6 & 0.387 & 0.392 & 1.030 \\
\hline & Wijk 07-70 & 4.400 & 2200 & 1.667 & LGM & 1.628 & 4.496 & 1.681 & 4.451 & 5.287 & 5 & 0.362 & 0.379 & 1.457 \\
\hline & Wijk 09-58 & 4.900 & 2450 & 1.491 & average & 1.389 & 5.002 & 1.470 & 4.951 & 5.310 & 5 & 0.278 & 0.304 & 2.306 \\
\hline \multirow[t]{2}{*}{ aff. N. pusillus } & SMNS 92125 & 1.810 & 1200 & 0.543 & average & 0.571 & 1.797 & 0.510 & 1.662 & 4.589 & 7 & 0.318 & 0.300 & 0.602 \\
\hline & SMNS 50372c & 1.715 & 1130 & 0.461 & average & 0.500 & 1.838 & 0.123 & 1.820 & 13.418 & 6 & 0.272 & 0.269 & 0.183 \\
\hline \multirow[t]{2}{*}{ N. pusillus } & $\mathrm{T} 4178$ & 1.750 & 1150 & 0.814 & average & 0.829 & 1.783 & 0.525 & 1.765 & 8.453 & 7 & 0.465 & 0.465 & 0.401 \\
\hline & $\mathrm{T} 4211$ & 1.650 & 1085 & 1.039 & average & 0.360 & 1.658 & 0.676 & 1.643 & 10.789 & 8 & 0.217 & 0.630 & 0.278 \\
\hline \multirow[t]{2}{*}{ N. edwardsii } & T 4758 & 2.870 & 600 & 0.866 & LGM & 0.933 & 2.804 & 1.011 & 2.776 & 9.638 & 5 & 0.333 & 0.302 & 0.265 \\
\hline & phz 153 & 3.970 & 832 & 0.814 & average & 0.877 & 6.518 & 2.772 & 6.477 & 43.022 & 8 & 0.136 & 0.205 & 0.159 \\
\hline \multirow[t]{2}{*}{ Serpianosaurus } & T 4510 & 3.000 & 355 & 0.840 & average & 0.402 & 4.457 & 3.940 & 4.413 & 57.549 & $12-13$ & 0.091 & 0.280 & 0.047 \\
\hline & Т 119 & 2.130 & 252 & 0.377 & average & 0.152 & 2.185 & 3.223 & 2.163 & 15.824 & $10-11$ & 0.064 & 0.177 & 0.044 \\
\hline
\end{tabular}

\subsection{Comparison of modeled growth curves}

Based on published data from Sander (1990), Klein (2010), and Hugi et al. (2011), and the study of their samples first hand, growth was also modeled for Anarosaurus and for Neusticosaurus spp. and Serpianosaurus. Growth in Dactylosaurus from the early Anisian and in aff. Neusticosaurus pusillus from late Ladinian southern Germany was modeled for specimens used in this study.
Overall, we were finally able to establish growth models for 13 specimens out of the entire pachypleurosaur sample comprising 31 humeri (Tables 1-3; Table S1 in the Supplement; Fig. 3): MB.R. 786, MB.R. 776.2 (both Dactylosaurus), Wijk 08-472, Wijk 07-70, Wijk 09-58 (all Anarosaurus), SMNS 92125, SMNS 50372c (both aff. Neusticosaurus pusillus), PIMUZ T 4178, PIMUZ T 4211 (both Neusticosaurus pusillus), PIMUZ T 4758, PIMUZ phz 153 (both Neusticosaurus edwardsii), PIMUZ T 4510, and 

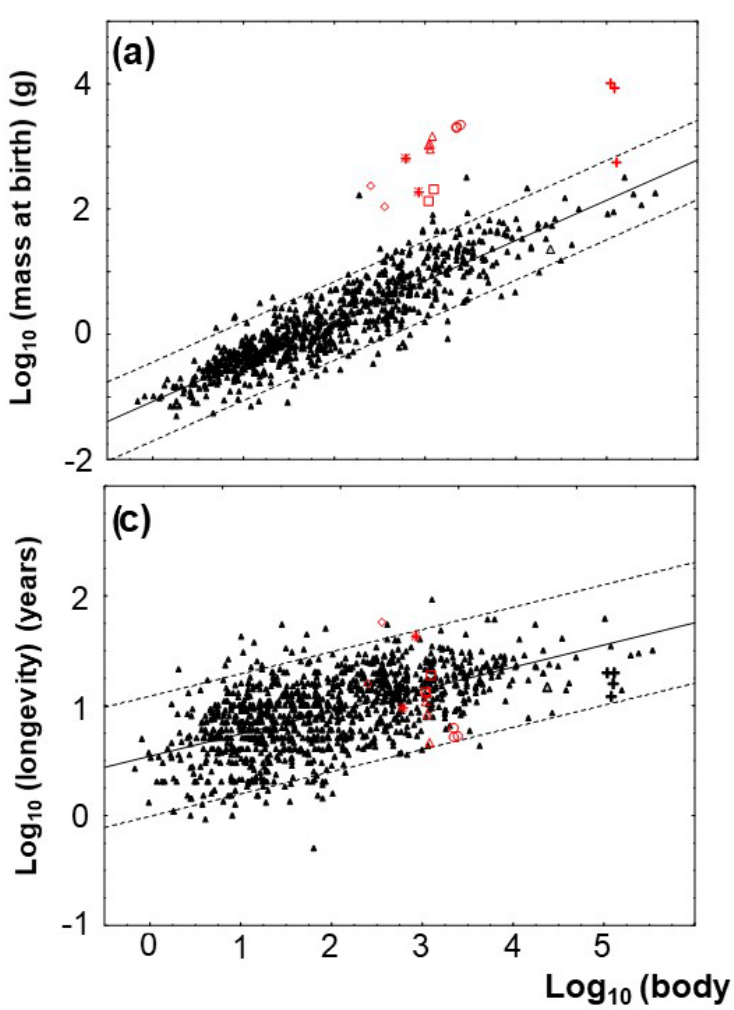
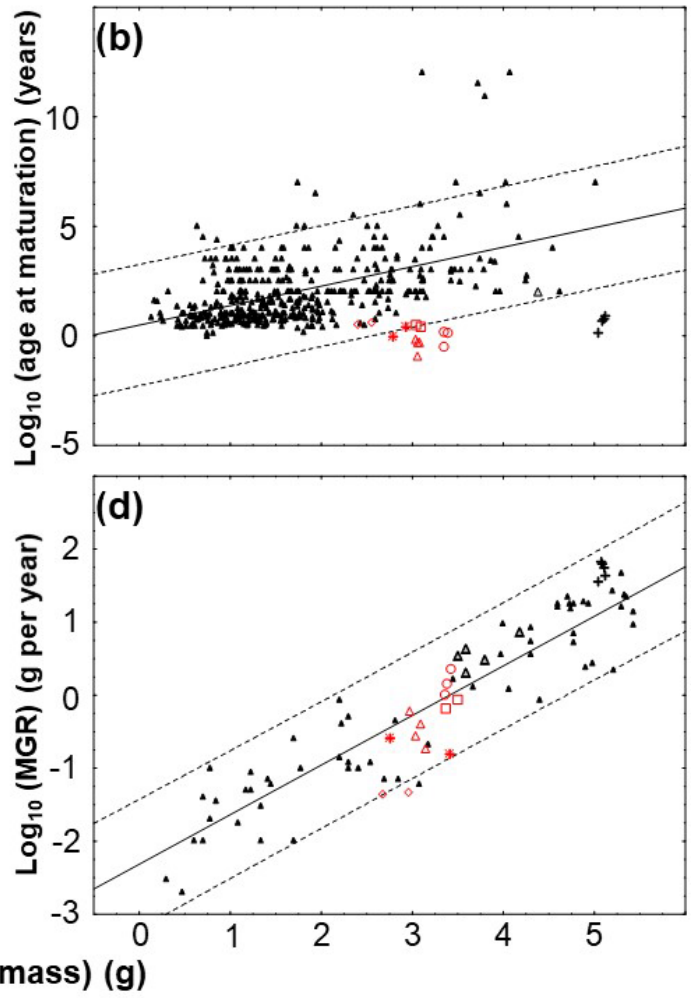

Figure 4. Allometric comparison of different life-history traits of pachypleurosaurs and Simosaurus to extant reptiles. (a) Mass at birth vs. body mass, (b) age at which sexual maturity is reached vs. body mass, (c) longevity vs. body mass, and (d) maximum growth rates vs. body mass. In all panels black triangles mark extant reptile species, red symbols pachypleurosaurs, and black crosses the nothosaur genus Simosaurus (values taken from Klein and Griebeler, 2016). Red squares = Dactylosaurus, circles = Anarosaurus, triangles = aff. $N$. pusillus, triangle with cross $=N$. pusillus, asterisk $=N$. edwardsii, and diamond = Serpianosaurus. Ordinary least squares regression lines and $95 \%$ prediction intervals are shown for extant species. Varanus niloticus (grey triangle) is highlighted because it is only somewhat larger than the pachypleurosaurs studied here. Data on body mass, mass at birth $(N=782)$, age at which sexual maturity is reached $(N=411)$, and longevity $(N=1014)$ of extant squamates are compiled from Scharf et al. (2015). Data on body mass and maximum growth rate of reptiles (squamates, crocodiles, and turtles, $N=66$ ) are taken from Werner and Griebeler (2014). Masses at birth of pachypleurosaurs (and Simosaurus) are larger than expected from the $95 \%$ prediction interval for a similar-sized squamate, whereas pachypleurosaurs longevities and maximum growth rates (including that of Simosaurus) almost fit within the respective intervals. The majority of pachypleurosaurs reach sexual maturity earlier than expected for a similar-sized squamate. Overall, pachypleurosaurs (and Simosaurus) have a considerably higher mass at birth and they clearly mature earlier than a similar-sized squamate.

PIMUZ T 119 (both Serpianosaurus). Except for Wijk 0770 and PIMUZ T 4758, at least two standard growth models (vBGM, GGM or LGM) obtained are similarly well supported in terms of AIC values $(\triangle \mathrm{AIC} \leq 10$, Burnham and Anderson, 2002) for all specimens (Table S1). Only for $N$. edwardsii, were final growth models only moderately supported over a linear model ( $\triangle \mathrm{AIC} \leq 10$, Burnham and Anderson, 2002, Table S1). For all other specimens the hypothesis that the growth record covers only the quasi-linear phase of growth was clearly rejected ( $\triangle$ AIC of a linear model $>10$ ). Also for all specimens the exponential model (the growth record covers only growth acceleration) and the asymptotic model (the growth record covers only growth deceleration) were clearly rejected ( $\triangle$ AIC values of both models $>10$ ).

\subsubsection{Life-history traits, birth-to-adult ratio, and maximum growth rates derived from models}

Life-history traits $L_{\text {birth }}, \mathrm{AL}, \mathrm{ASM}, 99 \% \mathrm{AL}, \mathrm{AA}$, and AD derived from growth models differed between the five pachypleurosaur taxa. They also showed a low up to high variability within each of the five taxa (Table 2, Fig. 4). Estimated $L_{\text {birth }}$ were lowest in Serpianosaurus (range in $L_{\text {birth }}$ : $0.152-0.402 \mathrm{~cm}$ ) and highest in Anarosaurus (1.389-1.706). Dactylosaurus (0.913-1.210), N. edwardsii, (0.877-0.933), $N$. pusillus $(0.360-0.829)$, and aff. $N$. pusillus $(0.500-0.571)$ had intermediary $L_{\text {birth. Neusticosaurus pusillus (the largest }}$ $L_{\text {birth }}$ is 2.3 times higher than that of the smallest) and Serpianosaurus (2.6 times) showed the strongest withintaxon variability in $L_{\text {birth }}$ and $N$. edwardsii (1.1 times) the lowest. In Dactylosaurus (1.3 times) and Anarosaurus (1.2 
times) within-taxon variability was somewhat higher than in N. edwardsii. AL and 99\%AL were lowest in N. pusillus (AL: 1.658-1.783 cm; \%99AL: $1.662-1820 \mathrm{~cm}$ ) and in aff. N. pusillus (AL: 1.797-1.838; \%99AL: 1.662-1.820). AL and $99 \% \mathrm{AL}$ showed the highest variability within $N$. edwardsii (AL: 2.804-6.518, 2.3 times; \%99AL: 2.7766.477, 2.3 times), and the lowest within Anarosaurus (AL: 4.409-5.002, 1.1 times; \%99AL: 4.365-4.951, 1.1 times). Within-taxon variability in AL and 99\%AL was lower in Anarosaurus than in Dactylosaurus (AL: 4.479-5.444, 1.2 times; \%99AL: 4.434-5.390, 1.2 times) and Serpianosaurus (AL: 2.185-4.457, 2.0 times; \%99AL: 2.163-4.413, 2.0 times). Estimated AA values were highest in Serpianosaurus (15.824-57.547 years) and lowest in Anarosaurus (5.2876.331). Within taxon variability AA was considerably larger in N. edwardsii (9.638-43.022, 4.5 times) and Serpianosaurus (5.824-57.549, 3.6 times) than in the three other pachypleurosaur taxa (Dactylosaurus: 9.149-13.548, 1.5 times; Anarosaurus: 5.287-6.331, 1.2 times; N. pusillus: 4.589-13.418, 2.9 times). Except for three specimens, for which models estimated that growth marks are missing in the inner part of the bone (PIMUZ T $4211 \mathrm{~N}$. pusillus; PIMUZ T 4510 and PIMUZ T119, Serpianosaurus) AD coincided with the numbers of growth marks preserved, and thus life spans documented in the growth record of specimens.

Models estimated ASM within the first year of life for all specimens from $N$. pusillus, within the first or the second year of life for Anarosaurus, within the second or third year of life for N. edwardsii, within the second and the fourth year of life in Dactylosaurus, and within the fourth year of life for Serpianosaurus. When ASM was related to AA and AD (relative onset of maturation within maximum life time) this ranking in ASM of taxa disappeared due to the large withintaxon variability in AA and AD, and also because for most of our specimens modeled AD were considerably smaller than AA (Table 2). Nevertheless, when relating ASM to AA, all specimens were sexually mature within the first third of their life, whereas $N$. pusillus and aff. N. pusillus even reached maturation within the first tenth of life.

Modeled $L_{\text {birth }}$ ToAL of pachypleurosaurs ranged between 0.064 and 0.465 (Table 2). The lowest ratios were seen in Serpianosaurus $(0.064,0.091)$. When using humerus lengths at the first growth mark preserved and humerus length at death length ratios $L_{1 \mathrm{gm}}$ To $L_{\text {lastgm }}$ ranged from 0.177 to 0.630 (Table 2).

Estimated MGR values were lowest in Serpianosaurus (0.044-0.047 $\mathrm{g} \mathrm{day}^{-1}$ ) and highest in Anarosaurus (1.030$\left.2.306 \mathrm{~g} \mathrm{day}^{-1}\right)$. Dactylosaurus $\quad\left(0.672-0.882 \mathrm{~g} \mathrm{day}^{-1}\right)$, N. pusillus $\left(0.278-0.401 \mathrm{~g} \mathrm{day}^{-1}\right)$, N. edwardsii (0.159$0.265 \mathrm{~g} \mathrm{day}^{-1}$ ), and aff. N. pusillus from the Germanic Basin had intermediary MGR values. MGR values varied considerably within Anarosaurus (the largest MGR is 2.2 times higher than that of the smallest), N. pusillus (3.3 times), and aff. $N$. pusillus (1.4 times). For mass-specific maximum growth rate (MGR/asymptotic mass or MGR/mass at

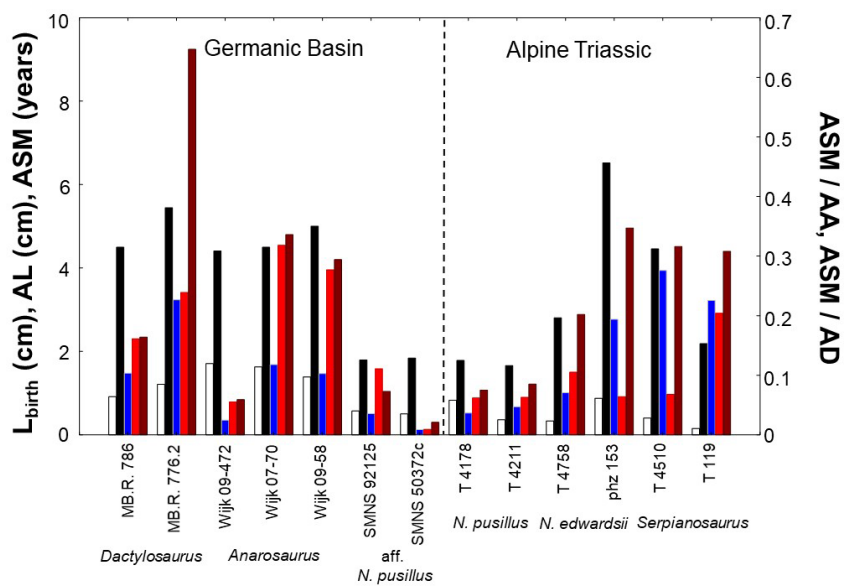

Figure 5. Comparison of humerus length at birth $\left(L_{\text {birth }}\right)$, asymptotic length (AL), age at which sexual maturity is reached (ASM), and onset of maturation for pachypleurosaurs with a modeled growth record. Onset of maturation within life is estimated as ratio of the age at which sexual maturity is reached and asymptotic age (ASM / AA). It is also assessed as ratio of the age at which sexual maturity is reached and age at death (ASM / AD). White $=L_{\text {birth }}$, black $=\mathrm{AL}$, blue $=\mathrm{ASM}$, red $=\mathrm{ASM} / \mathrm{AA}$, and brown $=$ ASM $/$ AD. High within-taxon variability in traits could suggest a sexual dimorphism in size and maturation in pachypleurosaur taxa. For values of life-history traits of specimens refer to Table 2, and for ratios to Table 3.

death, Table 3) this clear ranking in maximum growth increment disappeared, except for Serpianosaurus having again the lowest values.

\subsubsection{Evidence for sexual-size dimorphism as derived from growth models}

Two different growth and maturation strategies (please note that the inflection point of the growth curve sets ASM and thus the maturation strategy is implicitly given by the growth strategy) were observed within pachypleurosaur taxa (Figs. 3, 5). These different growth strategies coincide with the above described differences between life history traits, birth-to-adult size ratios, and maximum mass gain during life seen between and within taxa. Different growth strategies could indicate a sexual dimorphism in size and maturation in these taxa (Stamps, 1993; Stamps and Krishnan, 1997; see below).

In Dactylosaurus, both sexes start from rather similar $L_{\text {birth }}$ but the putative sex with the higher asymptotic size (MB.R. 776.2) matures later than that with the lower size (MB.R. 786). This in turn implies an earlier onset of maturation within life (absolute ASM, and relative ASM / AA, ASM / AD, Fig. 5) in MB.R. 786 than in MB. R. 776.2. Contrary, in Anarosaurus the specimens Wijk 09-472 and Wijk 07-70 have very similar $L_{\text {birth }}$ and AL, but Wijk 09472 matures one year earlier in life than Wijk 07-70, and 
Table 3. Growth and maturation strategies derived from best growth models established for specimens. For 2 out of the 13 specimens one standard growth model was clearly statistically supported, whereas for the other specimens at least two models fitted similarly well in terms of AIC. Abbreviations: $\mathrm{bl}=$ bone length, see Table 1; mass = mass of the specimen estimated from bl, see $\mathrm{Supplement} \mathrm{S} 1$; $\mathrm{bl}_{1 \mathrm{gm}}=\mathrm{bone}$ length corresponding to the first growth mark preserved; model: LGM = logistic growth model, average $=$ values of life-history traits and ratios are averages calculated from their best growth models based on Akaike weights (Table 2); Asymp. mass = mass estimated for $99 \%$ of asymptotic length; ASM / AA = ratio of age at which sexual maturity is reached and asymptotic age (relative onset of maturation within maximum life time); $\mathrm{ASM} / \mathrm{AD}=$ ratio of age at which sexual maturity is reached and age at death (relative onset of maturation within the individual's life); MGR / Asympt. mass = ratio of maximum growth rate and Asympt. mass (mass-specific maximum gain in body mass, relative to asymptotic mass); MGR / mass = ratio of maximum growth rate and mass (mass-specific maximum gain in body mass, relative to mass). For values on ASM, AA, AD, and MGR refer to Table 2.

\begin{tabular}{|c|c|c|c|c|c|c|c|c|c|c|}
\hline & Bone spec. no. & $\begin{array}{r}\mathrm{bl} \\
(\mathrm{cm})\end{array}$ & $\begin{array}{r}\text { mass } \\
(\mathrm{g})\end{array}$ & $\begin{array}{r}\mathrm{bl}_{1 \mathrm{gm}} \\
(\mathrm{cm})\end{array}$ & model & $\begin{array}{r}\text { Asymp. } \\
\text { mass }\end{array}$ & ASM / AA & $\mathrm{ASM} / \mathrm{AD}$ & $\begin{array}{l}\text { MGR / Asympt. } \\
\text { mass }\left(\text { day }^{-1}\right)\end{array}$ & $\begin{array}{r}\text { MGR / mass } \\
\left(\text { day }^{-1}\right)\end{array}$ \\
\hline \multirow[t]{2}{*}{ Dactylosaurus } & MB.R. 786 & 4.400 & 1239 & 0.970 & average & 2308.679 & 0.161 & 0.164 & 0.0003 & 0.0005 \\
\hline & MB.R. 776.2 & 3.820 & 1075 & 1.216 & average & 3118.347 & 0.239 & 0.647 & 0.0003 & 0.0008 \\
\hline \multirow[t]{3}{*}{ Anarosaurus } & Wijk 09-472 & 4.350 & 2175 & 1.704 & average & 2264.776 & 0.055 & 0.059 & 0.0005 & 0.0005 \\
\hline & Wijk 07-70 & 4.400 & 2200 & 1.667 & LGM & 2347.039 & 0.318 & 0.336 & 0.0006 & 0.0007 \\
\hline & Wijk 09-58 & 4.900 & 2450 & 1.491 & average & 2606.367 & 0.277 & 0.294 & 0.0009 & 0.0009 \\
\hline \multirow[t]{2}{*}{ aff. N. pusillus } & SMNS 92125 & 1.810 & 1200 & 0.543 & average & 920.651 & 0.111 & 0.073 & 0.0007 & 0.0005 \\
\hline & SMNS 50372c & 1.715 & 1130 & 0.461 & average & 1376.688 & 0.009 & 0.021 & 0.0001 & 0.0002 \\
\hline \multirow[t]{2}{*}{ N. pusillus } & Т 4178 & 1.750 & 1150 & 0.814 & average & 1215.601 & 0.062 & 0.075 & 0.0003 & 0.0003 \\
\hline & $\mathrm{T} 4211$ & 1.650 & 1085 & 1.039 & average & 1087.671 & 0.063 & 0.085 & 0.0003 & 0.0003 \\
\hline \multirow[t]{2}{*}{ N. edwardsii } & T 4758 & 2.870 & 600 & 0.866 & LGM & 1215.601 & 0.105 & 0.202 & 0.0002 & 0.0004 \\
\hline & phz 153 & 3.970 & 832 & 0.814 & average & 1087.671 & 0.064 & 0.347 & 0.0002 & 0.0002 \\
\hline \multirow[t]{2}{*}{ Serpianosaurus } & $\mathrm{T} 4510$ & 3.000 & 355 & 0.840 & average & 559.312 & 0.068 & $0.303-0.328$ & 0.0001 & 0.0001 \\
\hline & Т 119 & 2.130 & 252 & 0.377 & average & 355.000 & 0.204 & $0.293-0.322$ & 0.0001 & 0.0002 \\
\hline
\end{tabular}

shows a much earlier onset of maturation when ASM is compared to AA and AD (Fig. 5). The pattern in growth and maturation documented in Dactylosaurus is also seen in aff. N. pusillus (Fig. 5). SMNS 92125 and SMNS 50372c have rather similar $L_{\text {birth }}$, but SMNS 92125 has a smaller AL than SMNS 50372c, and sexual maturation is much earlier (absolute and relative) reached in SMNS 50372c than in SMNS 92125. Contrary, N. pusillus from the Alpine Triassic (PIMUZ T 4178 and PIMUZ T 4211) reach rather similar $\mathrm{AL}$, but their $L_{\text {birth }}$ differ more strongly than between SMNS 92125 and SMNS 50372c, and they show no clear differences in ASM, ASM / AA, and ASM / AD (Fig. 5). Neusticosaurus edwardsii resembled the growth strategies and maturation patterns seen in aff. N. pusillus (Fig. 5). The N. edwardsii specimens PIMUZ phz 153 and PIMUZ T 4758 have rather similar $L_{\text {birth }}$, but reach considerably differing $\mathrm{AL}$ and also differ in onset of maturation (absolute and relative). The two specimens PIMUZ T 4510 and PIMUZ T 119 of Serpianosaurus have differing $L_{\text {birth }}$ and $\mathrm{AL}$, and show differences within their life history only in the onset of sexual maturation for ASM / AA (Fig. 5).

\section{Discussion}

\subsection{Histological and microanatomical features}

\subsubsection{Microanatomy}

Microanatomy indicates osteosclerosis as typical secondary aquatic adaptation in all studied pachypleurosaurs, except for Anarosaurus. Contrary to the other pachypleurosaurs, Anarosaurus retained a large free central medullary cavity and is in this aspect plesiomorphic (i.e., closer to the ancestral terrestrial condition). It is thus less adapted to an aquatic environment. The stratigraphically older Dactylosaurus, which inhabited the Germanic Basin as well, has (as with Neusticosaurus spp. and Serpianosaurus from the Alpine Triassic) an already reduced free medullary cavity and thus displays osteosclerosis. Microanatomical differences might result from the near coastal environment documented for Winterswijk vs. the shallow marine conditions during the deposition of the Gogolin Formation. However, microanatomy of Dactylosaurus and of aff. N. pusillus also differs slightly from pachypleurosaurs from the Alpine Triassic in retaining a very small free cavity at midshaft whereas the taxa from the Alpine Triassic have filled nearly all cavities by endosteal bone. 


\subsubsection{Is the sharp line homologous to Kastschenko's line?}

The sharp line described herein as well as by several authors having studied long bone histology of Triassic sauropterygians (Sander, 1990; Klein, 2010; Hugi et al., 2011; Klein et al., 2015a, b, 2016) is similar to the Kastschenko's line described in long bones of amphibians (e.g., Castanet and Smirina, 1990; Francillon-Vielleit et al., 1990) and might be homologous to this. Kastschenko's line corresponds to thin remains of the embryonic cartilage matrix at the border of the medullary cavity and separates the endosteal from the periosteal region. In amphibians it is considered as evidence that the growth record is complete because it indicates that endosteal bone resorption and remodeling have not removed the first periosteal deposition yet (Castanet and Smirina, 1990; Francillon-Vielleit et al., 1990). However, in Sauropterygia the sharp line occurs only in non-midshaft samples and the destruction of inner cycles is here likely because loss of inner cycles in non-midshaft samples is documented in some specimens for which a midshaft and a more proximal or distal sample does exist.

\subsection{3 (Pre-)hatchling bone tissue}

Dactylosaurus, Anarosaurus, and aff. N. pusillus all from the Germanic Basin display a distinct change in tissue in their innermost cortex; here interpreted as a transition from prehatchling or hatchling bone tissue to "normal" periosteal bone growth. It only occurs in midshaft samples (Table 1). We hypothesize that this change in tissue indicates an important event in the individual's life history such as hatching (prehatching tissue) or a switch in the hatchling's diet (resorbing the yolk, hatchling tissue vs. foraging start of "normal" periosteal bone growth). This inner bone tissue is usually not documented in pachypleurosaur samples from the Alpine Triassic (Hugi et al., 2011; Nicole Klein, personal observation, 2017). However, it is also less clear in Anarosaurus.

Some individuals that exhibit this tissue start growth fast (i.e., with a zone) and others slowly (i.e., with an annulus). This might indicate two breeding, egg laying, and hatchling periods during a season or year, giving rise to two sub cohorts a year. Producing several clutches a season is known for many reptiles. However, to our knowledge no histological study of a population had ever focused on differences in the inner tissue. Thus, our hypothesis remains quite hypothetical until this is studied in modern reptiles. In addition, one has to consider that our sample does not represent a single population but consists of individual specimens, of which many were found in different localities (= environments) and which had not lived at the same time. Therefore, climatic and environmental differences between localities as well as in time must be considered as well.

\subsubsection{Layer of highly organized, and perpendicularly oriented fine fibers}

In some samples the inner remains of (pre-)hatchling tissue are surrounded by a distinct layer of highly organized, and perpendicularly oriented fine fibers, which are very distinct in polarized and in normal light. Although this layer is very distinct we do not interpret it as 1st annual growth mark because it does not occur in all samples that have (pre-)hatchling tissue and the tissue is very different from the tissue usually forming typical annuli or LAGs. This layer might indicate a period of rest after hatching (resorbing the rest of the yolk, although already hatched) or biomechanical changes (e.g., locomotion, skin attachment). The distinct layer of highly organized and perpendicularly oriented fine fibers is usually not documented in pachypleurosaurs from the Alpine Triassic.

\subsection{Life-history traits}

\subsubsection{General aspects}

Bone tissue and growth rate strongly underlie individual variation, i.e., developmental plasticity in all Triassic Sauropterygia studied so far (Klein, 2010; Hugi et al., 2011; Klein et al., 2015a, b, 2016; Klein and Griebeler, 2016). Differences related to environmental conditions experienced by taxa under study are obvious as well. They originate from different localities and most likely lived at different times besides overall different stratigraphic origins. Only the sample of Anarosaurus originates from the same locality and horizon. Even here differences in bone tissue, vascularization, vascular density, and microanatomy exist. The length of the time period during which the bones of Anarosaurus accumulated is unclear and could have lasted decades to thousands of years. Moreover, at the same locality even within a year exogenous condition can vary greatly. The four different pachypleurosaurs taxa from the Alpine Triassic occur subsequently in four different horizons (summarized in Hugi et al., 2011). All other samples originate from different localities and horizons. Thus, climate as well as other exogenous conditions (e.g., sea level, food availability) have varied considerably. Besides exogenous factors endogenous conditions (e.g., fitness of female and individual) must be considered.

Also, as a result of the above mentioned factors, the sequences of growth marks are very variable in pachypleurosaurs. They rather seem to indicate individual and environmental variability than taxonomy, as does the presence of subcycles and double LAGs. Sexual dimorphism as a further source of within-taxon variability is also a likely factor for high variability (Sander, 1989; Lin and Rieppel, 1998; Cheng et al., 2004, 2009; Xue et al., 2015; discussed below).

Dactylosaurus and aff. N. pusillus were small pachypleurosaurs $(\sim 50 \mathrm{~cm}$ body length) with a relatively short life span. Based on their preserved growth record, both taxa 
reached sexual maturity early in life, after the 1 st or 2 nd year. Maturation is marked by a distinct LAG accompanied by an increase in tissue organization and a decrease in vascular density. After the 4th year of life, growth rate increases again because growth marks become closely spaced and mark attainment of maximum size. While growth models resembled ages at which sexual maturity is documented in the growth record for Dactylosaurus (within the 2nd or 4th year of life), they indicated sexual maturation already within the first year of life in aff. $N$. pusillus. Given the short life span in aff. $N$. pusillus this difference in onset of maturation is large (the preserved growth record indicates it after two years and the models within the 1st year of life). Overall, life-history traits derived from models on aff. N. pusillus and N. pusillus were rather similar and comprised a similar amount of variability within both taxa. This supports the hypothesis that both groups belong to the same taxon.

Growth models corroborated that Serpianosaurus reached sexual maturity in its 2nd or 3rd year of life (Hugi et al., 2011) as they predict maturation in the fourth year of life. Model estimates on ages at death were lower than 14 years for our two specimens modeled, which is consistent with Hugi et al. (2011). Compared to the observation of Hugi et al. (2011) that the onset of sexual maturity started in $N$. edwardsii between the 4th and 7th year, our growth models suggested a much earlier maturation after the 1st or 2 nd year of life. However, our asymptotic ages derived from models (maximum life span) corroborate that an individual from this taxon could have lived longer than 15 years (Hugi et al., 2011). Overall, ages at onset of maturation derived from the growth record and estimated from growth curves of pachypleurosaurs were more or less consistent. They also agree with the overall range of values seen in extant squamates (within the first year of life up to 12 years, Fig. 4). When compared to similar-sized extant squamates, pachypleurosaur maturation ages are among the smallest seen in extant species or even smaller. Maturation in Simosaurus is also earlier than in a modeled similar-sized extant squamates (Klein and Griebeler, 2016; Fig. 4).

Except for the aff. N. pusillus specimen SMNS 92125, estimated asymptotic ages (i.e., when maximal size is reached) did considerably exceed estimated ages at death. This pattern was also observed in Placodontia and Simosaurus as was the early onset of sexual maturity (Klein et al., 2015b; Klein and Griebeler, 2016). All of this could indicate a large predation pressure on these taxa, preventing animals from reaching asymptotic age and size and favoring an early onset of maturation within their life in order to enable a successful reproduction before death (Sinclair et al., 2003; Owen-Smith and Mills, 2008). Estimated asymptotic ages of pachypleurosaurs are not only consistent within the range seen in extant squamates $(0.5-91.0$ years, $N=1014)$. They also resemble those seen in similar-sized extant squamates (Fig. 4). Compared to the other pachypleurosaurs studied and to the largerbodied Placodontia and Simosaurus, the estimated asymp- totic age of one Serpianosaurus specimen (PIMUZ T 4510, 57.5 years) and of one $N$. edwardsii specimen (PIMUZ phz $153,43.0$ years) was very high. However, AIC values of growth models on the two $N$. edwardsii specimens did not pass or only tightly passed (Serpianosaurus) our $\Delta$ AIC $\geq 10$ criterion to assure that the growth record does not only cover the quasi-linear phase of growth (Table S1).

Compared to similar-sized extant squamates, all pachypleurosaurs studied and also Simosaurus have larger masses at birth (Klein and Griebeler 2016; Fig. 4). This could indicate a smaller clutch size in these Sauropterygia than in similar-sized extant reptiles (Meiri et al., 2015).

Overall, a comparison of life-history strategies of pachypleurosaurs and Simosaurus to similar-sized extant reptiles (Fig. 4) indicates a similar asymptotic age, but an earlier onset of maturation within their life. The latter might compensate their lower clutch sizes due to larger birth sizes than in similar-sized extant squamates. Maximum growth rates of all pachypleurosaurs and of Simosaurus are again consistent with those seen in similar-sized extant reptiles (Fig. 4).

\subsubsection{Sexual dimorphism}

Humeral morphology of Dactylosaurus and aff. N. pusillus is variable. Nevertheless, a clear separation into a simple and a more complex morphology, reflecting sexual dimorphism between females and males as is known for Neusticosaurus spp. (Sander, 1989; Rieppel, 1989) and for Keichousaurus (Lin and Rieppel, 1998; Cheng et al., 2004, 2009; Xue et al., 2015 ) is not possible due to the low sample size studied on Dactylosaurus and aff. $N$. pusillus $(<10$ specimens' in this study vs. hundreds of specimens of pachypleurosaurs from the Alpine Triassic and China).

Pachypleurosaurs studied by us showed differences in the appearance and clarity and distinctness of growth marks within taxa (see Hugi and Sánchez-Villagra, 2012, for differences in growth marks in modern iguanids), and different growth and maturation strategies were identified by modeling. All these differences could indicate sexual dimorphism (Stamps, 1993; Stamps and Krishnan, 1997). However, environmental and individual variability could also generate these patterns, especially as sampled humeri do not originate from the same localities or horizons. That humeri studied might belong to different species would be a further explanation for the high variability in growth and maturation patterns but this problem is always present when studying extinct taxa.

Modeled birth sizes in Dactylosaurus and N. edwardsii differ among specimens. The putative sex with the higher asymptotic size matures later than that with the lower size, whereas the sex with the lower asymptotic size has an earlier onset of maturation within life (absolute and relative, Fig. 5). The aff. N. pusillus specimens had the same growth and maturation strategy as seen in Dactylosaurus and N. edwardsii (Fig. 5). Contrary, the N. pusillus specimens reach rather 
similar asymptotic sizes. The variability in size at birth was larger in N. pusillus than in aff. N. pusillus, whereas onset of sexual maturation shows a low variability within both taxa. Anarosaurus has very similar lengths at birth and similar asymptotic lengths, but show a strong difference in the onset of maturation (absolute and relative, Fig. 5). The two specimens from Serpianosaurus have differing lengths at birth and asymptotic sizes, and show large differences in the onset of sexual maturation within their life (only ASM / AD, Fig. 5). Thus, overall no uniform growth and maturation strategy is seen in the taxa from the Germanic Basin or from that from the Alpine Triassic. This suggests a high variability in growth and maturation strategies within pachypleurosaurs in space and in evolutionary time. Different environmental conditions and evolutionary history could had shaped differences in growth and maturation patterns seen between (putative) sexes.

As many situations exist that can lead to a sexual dimorphism in size and maturation it is difficult to assign a sex to a growth strategy for pachypleurosaurs and for fossils in general (where we have in addition the problem of unambiguous taxonomical assignment). For example, selection for larger male size and later onset of reproduction could be driven by male-male competition, i.e., by competition for mating opportunities, larger males have more reproductive success than smaller. This selection scenario seems to be applicable to a number of extant lizards (reviewed in Cox et al., 2003), in which males are larger than females. It would indicate that the larger pachypleurosaur specimens with the delayed maturity are indeed males. Territorial behavior that could lead to competition for mating opportunities has already been suggested to explain why males are larger than females in the Chinese pachypleurosaur Keichousaurus (Lin and Rieppel, 1998). Males can become double the size of the smallest pregnant female (Nicole Klein, personal observation, 2006, on Keichousaurus specimens in Yichang collection). However, extant lizard species in which females are larger than males also exist (reviewed in Cox et al., 2003) and thus both situations could have also existed in pachypleurosaurs. Fecundity selection favors large size and an earlier onset of maturation in females than in males, i.e., larger and earlier reproducing females can have more offspring during their life. However, the scenario that females are larger than males is not supported by our growth models. All specimens with a larger asymptotic size show a delayed (and not an earlier) sexual maturity compared to those with the other growth strategy (Fig. 5). For our pachypleurosaur sample selection for higher fecundity is only conceivable for Anarosaurus, in which onset of maturation but not birth size and asymptotic size differs between the putative sexes. In this case, Wijk 09472 would correspond to a female, because it has the earliest onset of maturation seen within our sample on this taxon. Finally, environmental conditions could also select for a sexual size dimorphism in order to reduce intraspecific competition between sexes for food (prey, dietary partitioning) or more generally lead to niche divergence of sexes (reviewed in Shine, 1989; Cox et al., 2007).

Differences in size and age at maturation of sexes are known for extant reptiles. They corroborate differences in asymptotic sizes and ages at which sexual maturation used by us to evidence sexes in pachypleurosaur taxa (Fig. 5, Tables 2 and 3). Males are larger than females in the majority of lizards, but species in which females are larger than males also exist. In some species of Anolis, Tropidurus, Amblyrhynchus, and Varanus males are on average $50 \%$ larger than females. By contrast, females exceed only males by as much as $20 \%$ in Polychrus, Mabuya, and Aprasia (reviewed in Cox et al., 2007). In snakes males are also more often larger than females. In large pythons (Morelia, Python) and boas (Eunectes) male body mass can even be an order of magnitude larger than female mass. In turtles, females are most frequently larger than males. This situation is seen in $50-60 \%$ of all turtle species. Size differences in turtles can be very impressive, e.g., in Kachuga and Graptemys females average two up to three times the length of males (reviewed in Cox et al., 2007). In large Alligator, Caiman, and Crocodylus species, males exceed females in length by 20 up to $40 \%$ (reviewed in Cox et al., 2007). However, unfortunately the majority of comparative studies on sexual dimorphism in extant reptiles have only focused on size differences between sexes, whereas much less is known in reptiles about differences in the onset of maturation between sexes. Nevertheless, several authors have shown differences in the relationship between size at maturation and asymptotic size in Anolis lizards, the rattlesnake Crotalus viridis, the lizards Sceloporus merriami and Ctenotus pantherinus, and the slider turtle Pseudemys scripta (reviewed in Stamps and Krishnam, 1997). An evaluation of the database AnAge (de Magalhães and Costa, 2009) yields a total of 14 reptile species (11 turtles, 3 squamates) in which females mature later than males. The female turtle species (Chelydra serpentina, Chrysemys picta, Deirochelys reticularia, Emydoidea blandingii, Malaclemys terrapin, Pseudemys concinna, Trachemys scripta, Kinosternon baurii, Kinosternon subrubrum, Stenotherus minor, Apalone mutica) are 1.2 up to 2.4 times later sexually mature than males, and female squamates (Lacerta vivipara, Virginia striatula, Crotalus horridus) are 1.3 up to 2.0 times later sexually mature than males.

\subsubsection{Viviparity}

The distinct layer of highly organized, and perpendicularly oriented fine fibers might be related to viviparity and indicate a period of rest after hatching or being born and before starting foraging by the individual. Viviparity in Sauropterygia was clearly documented for Keichousaurus (Cheng et al., 2004) and is very likely for Neusticosaurus spp. (Sander, 1988, 1989; Rieppel, 1989). It is also documented in plesiosaurs (O'Keefe and Chiappe, 2011), the 
descendants of Triassic Eosauropterygia. However, O'Keefe and Chiappe (2011) argued that the small specimen located within the larger specimen must be an embryo (and not prey) due to the high ratio in humeri length of the (putative) embryo and mother, which is always considered as being indicative for viviparity in extinct taxa.

$L_{\text {birth }}$ ToAL ratios derived from growth models for pachypleurosaurs studied ranged between 0.064 and 0.465 (Table 2). When using humerus lengths corresponding to the first growth mark and humerus length at death preserved in the growth record, $L_{1 \mathrm{gm}} \mathrm{To} L_{\text {lastgm }}$ values ranged from 0.177 to 0.630 (Table 2). When the first growth mark coincides with the individual's birth $L_{1 \mathrm{gm}} \mathrm{To} L_{\text {lastgm }}$, the birth-to-adult ratio is preserved in the individual itself. When the first growth mark was laid down after birth and thus later in ontogeny, $L_{1 \mathrm{gm}} \mathrm{To} L_{\text {lastgm }}$ overestimates the true value. Thus, overestimation is expected for specimens PIMUZ T 4211, PIMUZ T 4510, and PIMUZ T 119 in which growth marks could be missing (Table S1). Nevertheless, ranges obtained from different methods still match those observed for other viviparous fossils and Sauropterygia (please note that birth size in these fossils is most probably underestimated as embryos have not finished development) as well as those of extant viviparous reptiles. Specimens of Neusticosaurus in Sander $(1988,1989)$ show birth-to-adult ratios between 0.25 and 0.52 . These ratios match $L_{\text {birth }}$ ToAL ratios of PIMUZ $\mathrm{T} 4211$ (0.272) and PIMUZ T 4178 (0.465), but not that obtained from the length corresponding to the first growth mark for PIMUZ T $4211(0.639)$ as the growth models suggest for this specimen that two growth marks are missing. They also fit to those estimated for the N. edwardsii specimen PIMUZ T 4758 (0.333 and 0.302), but not to PIMUZ phz 153 (0.135 and 0.205). For the nothosaur Lariosaurus, Renesto et al. (2003) report a presumably birth-to-adult humerus ratio of 0.26 consistent with both ranges. While the cited studies on Neusticosaurus and Lariosaurus estimated lengths of hatchlings from isolated embryos, Cheng et al. (2004) and O'Keefe and Chiappe (2011) had pregnant females providing direct evidence of viviparity. Based on figures in Cheng et al. (2004) a ratio of 0.27 and 0.33 for two pregnant females of Keichousaurus was calculated, in this study. O'Keefe and Chiappe (2011) gave ratios between 0.4 and 0.67 for their pregnant plesiosaur. The scincid Egernia group (Egernia stokesii: ratio $=0.46$, Tiliqua rugosa: ratio $>0.5$, Corucia zebrata: ratio $=0.56$ ) listed in O'Keefe and Chiappe (2011) corroborates the high birth-to-mother ratios in the plesiosaur studied by these authors. They are also consistent with the high $L_{1 \mathrm{gm}} \mathrm{To} L_{\text {lastgm }}$ of the pachypleurosaurs studied here.

The selective pressures favoring viviparity over oviparity in the evolutionary history of vertebrates are diverse and highly discussed (Blackburn and Sidor, 2014). For pachypleurosaurs a selective advantage of viviparity could be that a female is able to reduce mortality within embryonal development in order to increase her reproductive success under high predation pressure. Alternatively, viviparity is the ancestral state for this taxon or even the entire group.

\subsubsection{Growth rates}

In all pachypleurosaurs, bone tissue type is lamellarzonal, implying relatively low growth rates, except for Anarosaurus. Anarosaurus grew with incipient fibrolamellar bone tissue type, combined with a higher vascular density, resulting in an increased growth rate. Compared to other Triassic Sauropterygia, Dactylosaurus and the Neusticosaurus-Serpianosaurus clade display the lowest growth rates based on tissue organization and vascular pattern and density (Klein et al., 2015a, b; Klein and Griebeler, 2016; Klein et al., 2016). MGR values obtained from growth models corroborate these histological findings (Tables 2 and 3). Serpianosaurus has the lowest mass-specific growth rate (MGR / asymptotic mass, MGR / mass at death, Table 3) of all pachypleurosaurs studied and compared to similarsized extant reptiles its MGR is even lower (Fig. 4, Table 3). Neusticosaurus edwardsii has the second lowest massspecific maximum growth rates in our sample. Rates of $N$. pusillus and that of Dactylosaurus are only slightly higher than those of $N$. edwardsii. MGR values and mass-specific growth rate of aff. $N$. pusillus show a higher variability than those of $N$. pusillus. This could indicate that the two taxa experienced different environmental conditions during growth (Alpine Triassic vs. Germanic Basin). Except for Anarosaurus, all MGR values of studied pachypleurosaurs are lower than that expected for a similar-sized extant reptile (Fig. 4). Our growth models corroborate that Anarosaurus specimens have the highest MGRs in the pachypleurosaurs sample. Histological studies suggest that growth rates in Anarosaurus are somewhat higher than the observed range in nothosaurs and that they are comparable to rates of pistosauroids (Klein, 2010; Klein et al., 2016). However, MGR values of Simosaurus are somewhat higher than those seen in modern similar-sized reptiles, and they are thus considerably higher than in Anarosaurus (scaled up to this size). Differences in growth rates could reflect differences between food availability and quality in Triassic marine ecosystems and today's terrestrial ecosystems.

In Placodontia, taxa studied from the Alpine Triassic showed lamellar-zonal bone tissue but taxa that lived within the Germanic Basin all displayed fibro-lamellar bone (Klein et al., 2015a, b). However, this might be related to taxonomical differences, low sample size, or simply may not reflect a true pattern. Nothosaurs all grew with lamellar-zonal bone but were so far only sampled from the Germanic Basin. Dactylosaurus from the Germanic Basin grew with lamellarzonal bone tissue, whereas Anarosaurus, also from the Germanic Basin, grew with incipient fibro-lamellar bone tissue (Klein, 2010). All pachypleurosaurs from the Alpine Triassic i.e., the Neusticosaurus-Serpianosaurus clade (including aff. $N$. pusillus from the Germanic Basin) also grew 
with lamellar-zonal bone tissue. It is not clear whether microanatomical and histological differences of Anarosaurus are solely related to the environmental settings or whether phylogenetic relationships of Anarosaurus should be rethought.

\section{Conclusions}

Histological analysis and growth curve modeling revealed important insights into growth and maturation strategies of European pachypleurosaurs. Pachypleurosaurs from the Germanic Basin show a (pre-)hatching bone tissue that is usually not documented in pachypleurosaurs from the Alpine Triassic.

Life-history traits derived from modeled growth of pachypleurosaur specimens were largely consistent with those preserved in the specimens' growth record. This study evidences an early onset maturation within life and higher asymptotic ages than ages at death. This pattern had been already observed in Placodontia (Klein et al., 2015b) and Simosaurus (Klein and Griebeler, 2016). We explain it by high predation pressures acting on individuals that prevented them from reaching asymptotic sizes within their life and favored early reproduction. Growth and maturation strategies showed a high variation within pachypleurosaur taxa, which could indicate sexual dimorphism in size and/or the onset of maturation. However, no uniform growth and maturation strategy was observed in pachypleurosaurs. This likely reflects that individuals lived not during the same time and many samples do not originate from the same localities. Different environmental conditions and other exogenous factors such as climate within a season, within years or even decades could have shaped strategies, too. High birth-to-adult size ratios in pachypleurosaurs studied were consistent with those of other viviparous fossil taxa (e.g., Keichousaurus, Cheng et al., 2004; Neusticosaurus spp., Sander, 1988, 1989) and with those of extant reptiles. Viviparity is also an advantage in predator-dominated environments and thus consistent with the growth and maturation strategies that our study evidenced for pachypleurosaurs.

Data availability. All necessary data are in the article.

Supplement. The supplement related to this article is available online at: https://doi.org/10.5194/fr-21-137-2018-supplement.

Author contributions. NK did the histological study and provided data for growth curve modeling. EMG did the growth curve modeling. Both authors prepared the manuscript.
Competing interests. The authors declare that they have no conflict of interest.

Special issue statement. This article is part of the special issue "Secondary adaptation of tetrapods to life in water - Proceedings of the 8th International Meeting, Berlin 2017'. It is a result of the 8th International Meeting on the Secondary Adaptation of Tetrapods to Life in Water, Berlin, Germany, 3-8 April 2017.

Acknowledgements. We acknowledge Olaf Dülfer (StIPB) and Christoph Wimmer-Pfeil (SMNS) for the production of the thin sections. We are grateful to the curators Rainer Schoch (SMNS) and Daniela Schwarz (MfN) who kindly gave us permission for bone histological sampling. Torsten Scheyer (PIMUZ) and Christian Klug (PIMUZ) gave us permission to study thin sections under the care of the PIMUZ and Martin Sander also provided specimens for study. We are grateful to the helpful comments of the reviewers Jorge Cubo and Elis Amson, and the editor Oliver Hampe.

Edited by: Oliver Hampe

Reviewed by: Jorge Cubo and Eli Amson

\section{References}

Andersson, M. B.: Sexual selection, Princeton University Press, 599 pp., 1994.

Blackburn, D. G. and Sidor, C. A.: Evolution of viviparous reproduction in Paleozoic and Mesozoic reptiles, Int. J. Dev. Biol., 58, 935-948, 2014.

Burnham, K. P. and Anderson, D. R.: Model selection and multimodal inference: a practical information-theoretic approach, Springer Verlag, Heidelberg, 488 pp., 2002.

Canoville, A. and Laurin, M.: Evolution of humeral microanatomy and lifestyle in amniotes, and some comments on palaeobiological inferences, Biol. J. Lin. Soc., 100, 384-406, 2010.

Castanet, J. and Smirina, E.: Introduction to the skeletochronological method in amphibians and reptiles, Ann. Sci. Nat., Zool. Biol Anim., 11, 191-196, 1990.

Cheng, Y.-N., Wu, X.-C., and Ji, Q.: Triassic marine reptiles gave birth to live young, Nature, 432, 383-386, 2004.

Cheng, Y.-N., Holmes, R., Wu, X.-C., and Alfonso, N.: Sexual dimorphism and life history of Keichousaurus hui (Reptilia: Sauropterygia), J. Vertebr. Paleontol., 29, 401-408, https://doi.org/10.1671/039.029.0230, 2009.

Cox, R. M., Skelly, S. L., and John-Alder, H. B.: A comparative test of adaptive hypotheses for sexual size dimorphism in lizards, Evol., 57, 1653-1669, 2003.

Cox, R. M., Butler, M. A., and John-Alder, H. B.: The evolution of sexual size dimorphism in reptiles, in: Sex, size, and gender roles, edited by: Fairbain, D. J., Blankenhorn, W. U., and Székely, T., Oxford University Press, Oxford, 38-49, 2007.

de Magalhães, J. P. and Costa, J.: A database of vertebrate longevity records and their relation to other life-history traits, J. Evol. Biol., 22, 1770-1774, 2009. 
Dunham, A. E.: Food availability as a proximate factor influencing individual growth rates in the iguanid lizard Sceloporus merriami, Ecology, 59, 770-778, 1978.

Dunham, A. E.: Populations in a fluctuating environment: the comparative population ecology of the iguanid lizards Sceloporus merriami and Urosaurus ornatus, Mics. Publ. Mus. Zool. Univ. Michigan, 158, 1-62, 1981.

Fraas, O.: Simosaurus pusillus aus der Lettenkohle von Hoheneck, Jahreshefte des Vereins für vaterländische Naturkunde in Württemberg, Stuttgart, 37, 319-324, 1881.

Fraas, O.: Die schwäbischen Trias-Saurier: nach dem Material der Kgl. Naturalien-Sammlung in Stuttgart zusammengestellt; mit Abbildungen der schönsten Schaustücke; Festgabe des Königlichen Naturalien-Cabinets in Stuttgart zur 42. Versammlung der Deutschen Geologischen Gesellschaft in Stuttgart, E. Schweizerbart (Koch), Stuttgart, 18 pp., 1896.

Francillon-Vieillot, H., Buffrénil de, V., Castanet, J., Géradudie, J., Sire, F. J., Zylberberg, I., and Ricqlés, A. de: Microstructure and mineralization of vertebrate skeletal tissues, in: Skeletal biomineralization: Patterns, Processes and Evolutionary Trends, edited by: Carter, J. G., Van Norstrand Reinhold, New York, 471-530, 1990.

Gürich, G. J. E.: Über einige Saurier des oberschlesischen Muschelkalkes, Ztschr. dt Geol. Ges., 36, 125-144, 1884.

Griebeler, E. M., Klein, N., and Sander, P. M.: Aging, maturation and growth of sauropodomorph dinosaurs as deduced from growth curves using long bone histological data: An assessment of methodological constraints and solutions, PLoS ONE, 8, e67012, https://doi.org/10.1371/journal.pone.0067012, 2013.

Hugi, J. and Sánchez-Villagra, M. R.: Histological and skeletochronological analyses on life history and skeletal adaptations in the marineiguana Amblyrhynchus cristatus and in other iguanas, J. Herpetol., 46, 312-324, 2012.

Hugi, J., Scheyer, T. M., Sander, P. M., Klein, N., and SánchezVillagra, M. R.: Long bone microstructure gives new insights into the life of pachypleurosaurids from the Middle Triassic of Monte San Giorgio, Switzerland/Italy, C. R. Palevol., 10, 413426, https://doi.org/10.1016/j.crpv.2011.03.009, 2011.

Jiang, D.-Y., Motani, R., Hao, W.-C., Rieppel, O., Sun, Y.-L., Schmitz, L., and Sun, Z.-Y.: First record of Placodontoidea (Reptilia, Sauropterygia, Placodontia) from the Eastern Tethys, J. Vertebr. Paleontol., 28, 904-908, https://doi.org/10.1671/02724634, 2008.

Klein, N.: Skull morphology of Anarosaurus heterodontus (Reptilia: Sauropterygia: Pachypleurosauria) from the Lower Muschelkalk of the Germanic Basin (Winterswijk, the Netherlands), J. Vertebr. Paleontol., 29, 665-676, 2009.

Klein, N.: Long bone histology of Sauropterygia from the Lower Muschelkalk of the Germanic Basin provides unexpected implications for phylogeny, PLoS ONE, 5, e11613, https://doi.org/10.1371/journal.pone.0011613, 2010.

Klein, N.: Postcranial morphology and growth of the pachypleurosaur Anarosaurus heterodontus (Sauropterygia) from the Lower Muschelkalk of Winterswijk, the Netherlands, Paleont. Z., 86, 389-408, https://doi.org/10.1007/s12542-012-0137-1, 2012.

Klein, N. and Griebeler, E. M.: Bone histology, microanatomy, and growth of the nothosaurid Simosaurus gaillardoti (Sauropterygia) from the Upper Muschelkalk of southern Germany/BadenWürttemberg, C. R. Palevol., 15, 147-167, 2016.
Klein, N. and Sander, P. M.: Bone histology and growth of the prosauropod Plateosaurus engelhardti Meyer, 1837 from the Norian bonebed of Trossingen (Germany) and Frick (Switzerland), Spec. Pap. Paleontol., 77, 169-206, 2007.

Klein, N., Houssaye, A., Neenan, J. M., and Scheyer, T. M.: Long bone histology and microanatomy of Placodontia (Diapsida: Sauropterygia), Contrib. Zool., 84, 59-84, 2015a.

Klein, N., Neenan, J. M., Scheyer, T. M., and Griebeler, E. M.: Growth patterns and life-history strategies in Placodontia (Diapsida: Sauropterygia), R. Soc. Open Sci., 2, 140440, https://doi.org/10.1098/rsos.140440, 2015b.

Klein, N., Sander, P. M., Krahl, A., Scheyer, T. M., and Houssaye, A.: Diverse aquatic adaptations in Nothosaurus spp. (Sauropterygia) - Inferences from humeral histology and microanatomy, PLoS ONE, 11, e0158448, https://doi.org/10.1371/journal.pone.0158448, 2016.

Krahl, A., Klein, N., Sander, P. M.: Evolutionary implications of the divergent long bone histologies of Nothosaurus and Pistosaurus (Sauropterygia, Triassic), BMC Evol. Biol., 13, 1-23, https://doi.org/10.1186/1471-2148-13-123, 2013.

Kupfer, A.: Sexual size dimorphism in amphibians: an overview, in: Sex, size and gender roles: Evolutionary Studies of Sexual Size Dimorphism, edited by: Fairbain, D. J., Blankenhorn, W. U., and Székely, T., Oxford University Press, Oxford, 50-59, 2007.

Kupfer, A., Kramer, A., and Himstedt, W.: Sex-related growth patterns in a caecilian amphibian (genus Ichthyophis): Evidence from Laboratory Data, J. Zool. Lond., 262, 173-178, 2004.

Lee, A. H. and Werning, S.: Sexual maturity in growing dinosaurs does not fit reptilian growth models, P. Natl. Acad. Sci. USA, 105, 582-587, 2008.

Lin, K. and Rieppel, O.: Functional morphology and ontogeny of Keichousaurus hui (Reptilia, Sauropterygia), Fieldiana Geol., N. S., 39, 1-35, 1998.

Liu, J., Rieppel, O., Jiang, D.-Y., Aitchison, J. C., Motani, R., Zhang, Q.-Y., Zhou, Ch.-Y., and Sun, Y.-Y.: A new pachypleurosaur (Reptilia: Sauropterygia) from the Lower Middle Triassic of southwestern China and the phylogenetic relationships of Chinese pachypleurosaurs, J. Vertebr. Paleontol., 31, 292-302, 2011.

Meiri, S., Feldman, A., and Kratochvíl, L.: Squamate hatchling size and the evolutionary causes of negative offspring size allometry, J. Evol. Biol., 28, 438-446, 2015.

Monnet, J.-M. and Cherry, M. I.: Sexual size dimorphism in anurans, P. Roy. Soc. Lond. B, 269, 2301-2307, https://doi.org/10.1098/rspb.2002.2170, 2002.

Myhrvold, N. P.: Revisiting the estimation of dinosaur growth rates, PLoS ONE, 8, e81917, https://doi.org/10.1371/journal.pone.0081917, 2013.

Nopcsa, F.: Palaeontological notes on reptiles, Geol. Hungaria, S. Pal., 1, 3-84, 1928.

O'Keefe, F. R. and Chiappe, L. N.: Viviparity and K-selected life history in a Mesozoic marine plesiosaur (Reptilia, Sauropterygia), Science, 333, 870-873, 2011.

Owen-Smith, N. and Mills, M. G. L.: Predator-prey size relationships in an African large-mammal food web, J. Anim. Ecol., 77, 173-183, 2008.

Pütter, A.: Wachstumsähnlichkeiten, Pflügers Archive für Gesamte Physiologie Menschen und Tiere, 180, 298-340, 1920.

Reiss, M. J.: The allometry of growth and reproduction, Cambridge University Press, Cambridge, 200 pp., 1989. 
Renesto, S., Lombardo, C., Tintori, A., and Danini, G.: Nothosaurid embryos from the Middle Triassic of northern Italy: An Insight into the Vivparity of Nothosaurs?, J. Vertebr. Paleontol., 23, 957960, 2003.

Rieppel, O.: A new pachypleurosaur (Reptilia: Sauropterygia) from the Middle Triassic of Monte San Giorgio, Switzerland, Philos. T. Roy. Soc. B, 323, 1-73, 1989.

Rieppel, O.: Sauropterygia I - Placodontia, Pachypleurosaurier, Nothosauroidea, Pistosauroidea, in: Encyclopedia of Paleoherpetology, edited by: Wellnhofer, P., Friedrich Pfeil Verlag, München, 1-134, 2000.

Rieppel, O. and Lin, K.: Pachypleurosaurs (Reptilia: Sauropterygia) from the Lower Muschelkalk, and a review of the Pachypleurosauroidea, Fieldiana Geol., N. S., 32, 1-44, 1995.

Ritz, J., Griebeler, E. M., Huber, R., and Clauss, M.: Body size development of captive and free ranging African spurred tortoises (Geochelone sulcata): high plasticity in reptilian growth rates, Herp. J. 20, 213-216, 2010.

Sander, P. M.: A fossil embryo from the Middle Triassic Alps, Science, 239, 780-783, 1988.

Sander, P. M.: The pachypleurosaurids (Reptilia: Nothosauria) from the Middle Triassic of Monte San Giorgio (Switzerland) with the description of a new species, Philos. T. Roy. Soc. B, 325, 561666,1989

Sander, P. M.: Skeletochronology in the small Triassic reptile Neusticosaurus, Ann. Sci. Nat., Zool. Biol. Anim., 11, 213-217, 1990.

Scharf, I., Feldman, A., Novosolov, M., Pincheira-Donoso, D., Das, I., Indraneil, D., Böhm, M., Uetz, P., Torres-Carvajal, O., Bauer, A., Roll, U., and Meiri, S.: Late bloomers and baby boomers: ecological drives of longevity in squamates and the tuatara, Global Ecol. Biogeogr., 24, 396-405, 2015.

Schoener, T. W. and Schoener, A.: Estimating and interpreting body-size growth in some Anolis lizards, Copeia, 1978, 390-405, 1978.

Seeley, H. G.: On Neusticosaurus pusillus (Fraas), an amphibious reptile having affinities with terrestrial Nothosauria and with marine Plesiosauria, Q. J. Geol. Soc., 38, 350-366, 1882.

Shang, Q. H., Wu, X. C., and Li, C.: A new eosauropterygian from Middle Triassic of eastern Yunnan Province, southwestern China, Vertebrata PalAsiatica, 49, 155-171, 2011.
Shine, R.: Ecological causes for the evolution of sexual dimorphism: a review of the Evidence, Q. Rev. Biol., 64, 419-461, 1989.

Sinclair, A. R. E., Mduma, S., and Brashares, J. S.: Patterns of predation in a diverse predator-prey system, Nature, 425, 288-290, 2003.

Stamps, J. A.: Sexual size dimorphism in species with asymptotic growth after maturity, Biol. J. Lin. Soc., 50, 123-145, 1993.

Stamps, J. A. and Krishnan, V. V.: Sexual bimaturation and sexual size dimorphism in animals with asymptotic growth after maturity, Evol. Ecol., 11, 21-39, 1997.

Stamps, J. A., Krishnan, V. V., and Andrews, R. M.: Analyses of sexual size dimorphism using null growth-based models, Copiea, 3, 598-613, 1994.

Stein, K. and Prondvai, E.: Rethinking the nature of fibrolamellar bone: an integrative biological revision of sauropod plexiform bone formation, Biol. Rev., 89, 24-47, 2013.

Sues, H.-D. and Caroll, R. L.: The pachypleurosaurid Dactylosaurus schroederi (Diapsida: Sauropterygia), Can. J. Earth. Sci., 22, 1602-1608, 1985.

von Bertalanffy, L.: A quantitative theory of organic growth, Hum. Biol., 10, 181-213, 1938.

Werner, J. and Griebeler, E. M.: Allometries of maximum growth rate versus body mass at maximum growth indicate that non-avian dinosaurs had growth rates typical of fast growing ectothermic sauropsids, PLOS ONE, 9, e88834, https://doi.org/10.1371/journal.pone.0088834, 2014.

Wu, X.-C., Cheng, Y.-N., Li, C., Zhao, L.-J., and Sato, T.: New Information on Wumengosaurus delicatomandibularis Jiang et al. 2008 (Diapsida: Sauropterygia), with a revision of the osteology and phylogeny of the taxon; J. Vertebr. Paleontol., 31, 70-83, 2011.

Xue, Y., Jiang, D., Motani, R., Rieppel, O., Sun, Y., Sun, Z., Ji, Ch., and Yang, P.: New information on sexual dimorphism and allometric growth in Keichousaurus hui, a pachypleurosaur from the Middle Triassic of Guizhou, South China, Acta Palaeontol. Pol., 60, 681-687, 2015. 